\title{
A STUDY ON JOB SATISFACTION AMONG CAMPUS RECREATION ADMINISTRATORS AT FOUR-YEAR PUBLIC AND PRIVATE INSTITUTIONS
}

\author{
A Dissertation \\ Presented to \\ The Graduate Faculty of The University of Akron
}

\author{
In Partial Fulfillment \\ of the Requirements for the Degree
}

Doctor of Education

Lance P. Kaltenbaugh

August, 2008 


\section{A STUDY ON JOB SATISFACTION AMONG CAMPUS RECREATION ADMINISTRATORS AT FOUR-YEAR PUBLIC AND PRIVATE INSTITUTIONS}

Lance P. Kaltenbaugh

Dissertation

Approved:

Advisor

Dr. Sandra Coyner

Committee Member

Dr. Xin Liang

Committee Member

Dr. Sharon Kruse

Committee Member

Dr. Megan Moore Gardner
Accepted:

Department Chair

Dr. Susan Olson

Dean of the College (Interim)

Dr. Cynthia Capers

Dean of the Graduate School

Dr. George Newkome

Committee Member

Dr. Alan Kornspan

Date 


\begin{abstract}
The primary purpose of this study was to investigate aspects of the job that influence job satisfaction among campus recreation administrators. Job satisfaction was measured by the Job Satisfaction Survey (JSS). Participants, consisting of 104 campus recreation administrators, were affiliated with the National Intramural Recreational Sports Association (NIRSA) of which encompasses all geographical regions in the United States. The JSS consisted of nine subscale measures that relate to employee job satisfaction and strongly examines perceptual and attitudinal variables (Spector, 1997). These nine factors include satisfaction with pay, promotional opportunities, fringe benefits, contingent rewards, supervision, co-workers, nature of work itself, communication, and work conditions.

According to the data, the degree to which campus recreation administrators are satisfied with their job is significant in two subscales. Results from this research suggest that supervision and nature of work were the two highest ranking measures of job satisfaction among campus recreation administrators at 4-year institutions. The second part of the Job Satisfaction Survey requested demographic information. Demographic items on the instrument included gender, age, population size of the institution, type of institution (public or private), and years of experience working as a campus recreation administrator. Results from this research suggest that the demographic information was not significant to explain the overall level of job satisfaction.
\end{abstract}




\section{ACKNOWLEDGMENTS}

First of all, I would like to thank my wife, Amanda, and our children for their understanding, patience, and support throughout this entire program. Thank you for being tolerant of a husband and father who was, more times than not, preoccupied with this study. Your continuous messages of love and encouragement throughout my dissertation journey made it possible for me to achieve my doctorate degree.

I would like to thank Dr. Sandy Coyner, my advisor and dissertation chair, for her guidance and support throughout this process. I would also like to express my gratitude to Dr. Xin Liang, Dr. Sharon Kruse, Dr. Megan Moore Gardner, and Dr. Alan Kornspan for their time and expertise. Thank you for forcing me to think critically about issues and concepts that I had not previously considered and challenging me to become a better writer and researcher. Working with each member of my committee has been a rigorous yet enjoyable experience.

Thank you to my parents, Pete and Janice, who have always believed in me. Words cannot express how deeply grateful I am for the love and support you have given me through my many life adventures. You have always modeled for me what excellence in all endeavors looks like. Thank you.

Thank you to all my friends, students, educators, and colleagues who helped in this dissertation and offered feedback and advice. I owe you a great deal. 
TABLE OF CONTENTS

Page

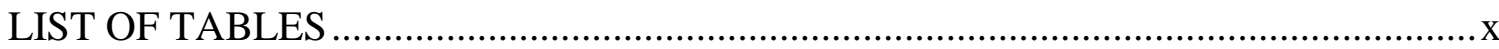

\section{CHAPTER}

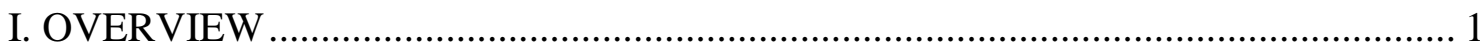

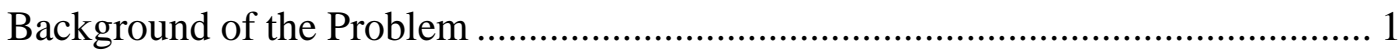

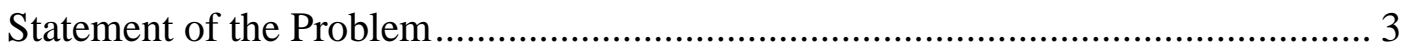

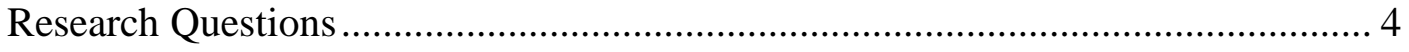

Professional Significance of the Study ............................................................ 5

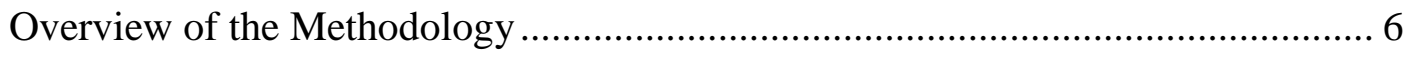

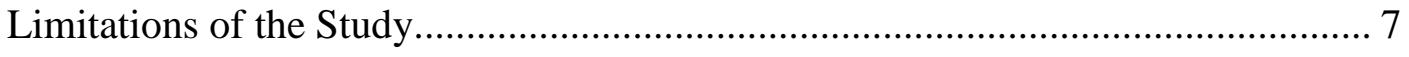

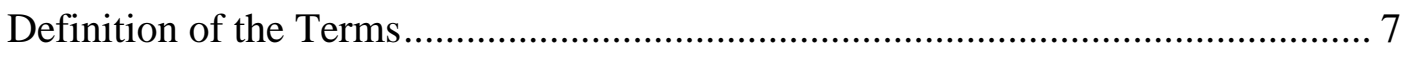

II. REVIEW OF THE LITERATURE .................................................................. 10

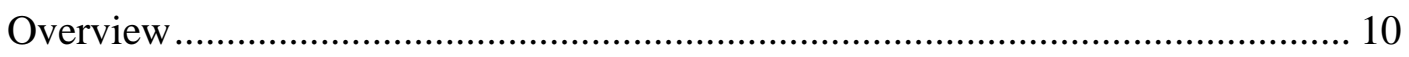

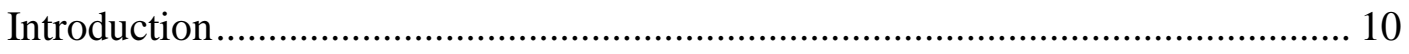

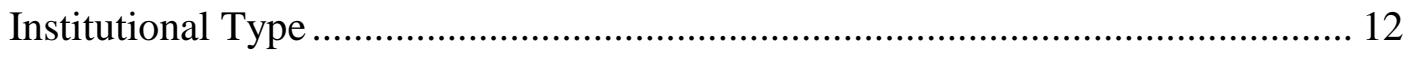

Student Affairs and the Co-Curricular Learning Environment................................ 15

Principles That Guide Student Affairs Work ........................................................ 17

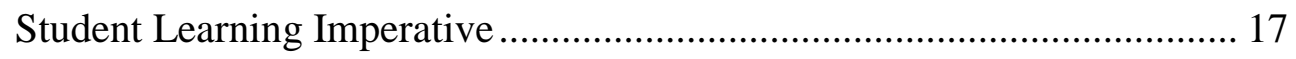

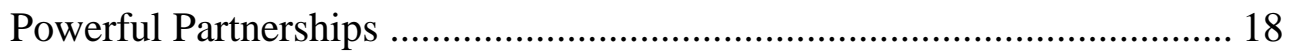


Principles of Good Practice....................................................................... 18

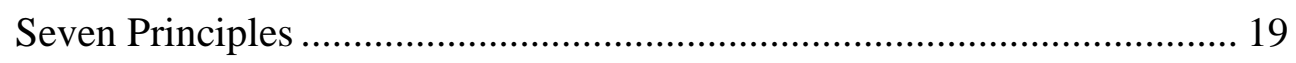

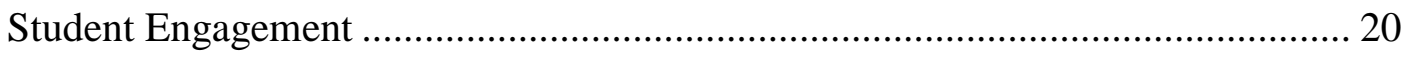

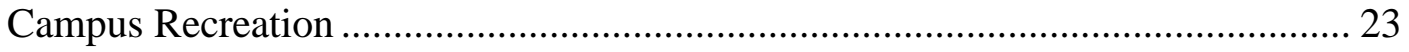

Defining Campus Recreation....................................................................... 25

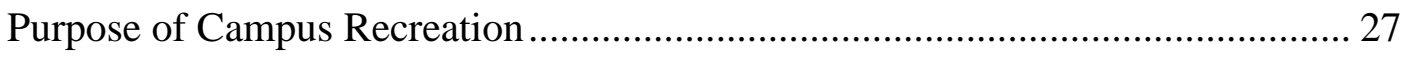

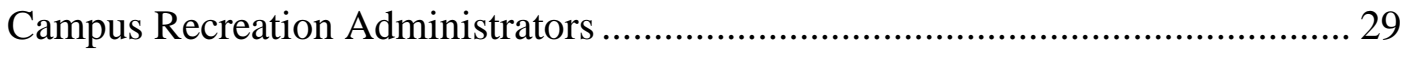

Challenges for Campus Recreation Administrators............................................... 30

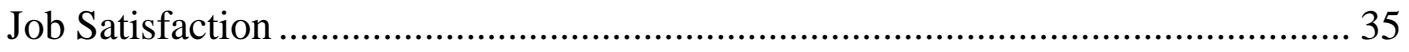

Job Satisfaction in Higher Education................................................................. 38

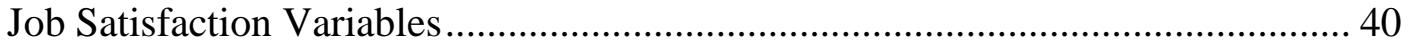

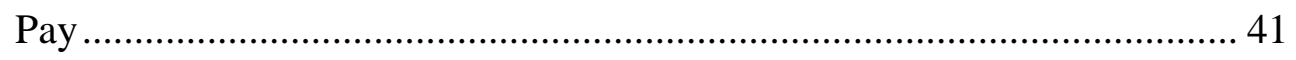

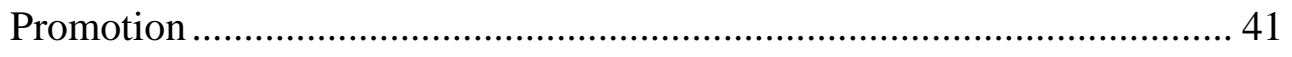

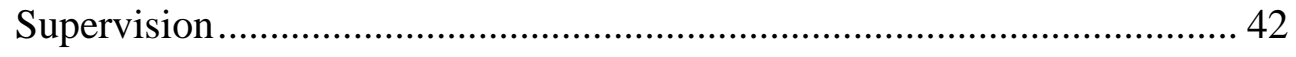

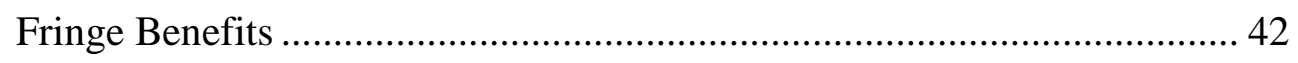

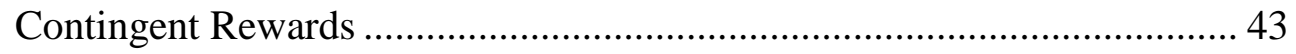

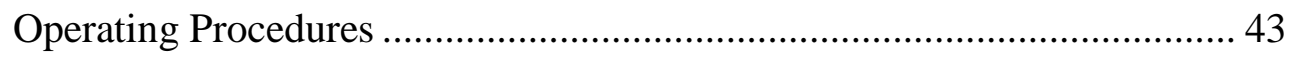

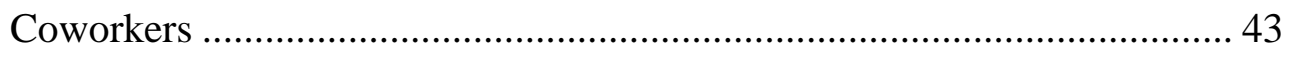

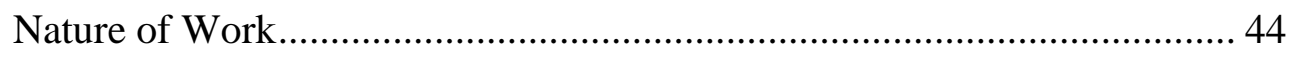

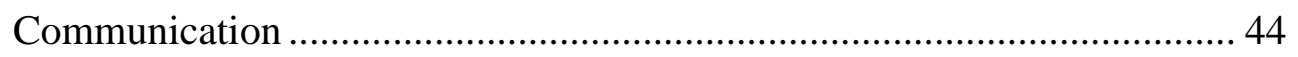

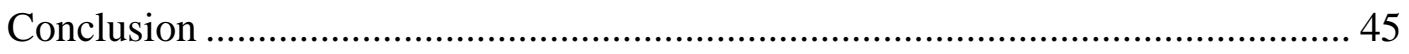

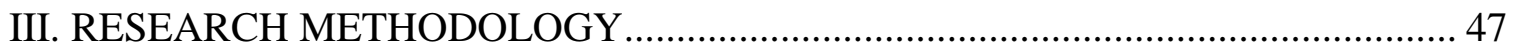




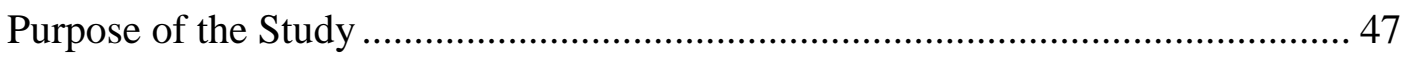

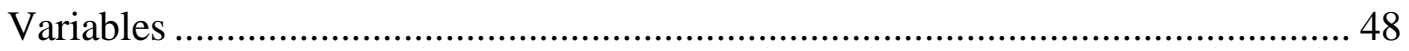

Research Questions .................................................................................. 48

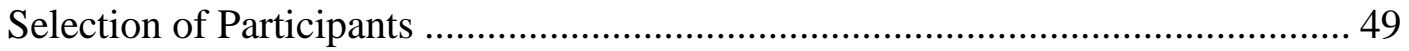

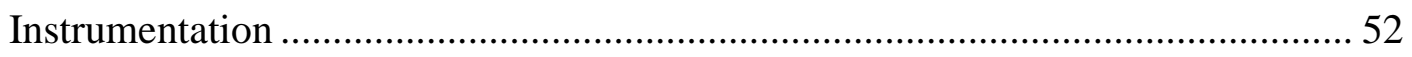

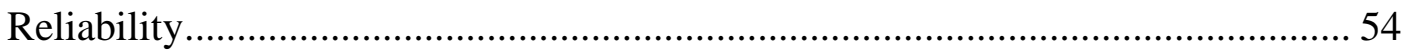

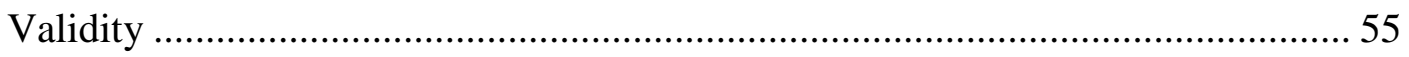

Data Collection Procedures........................................................................ 57

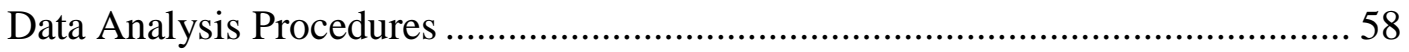

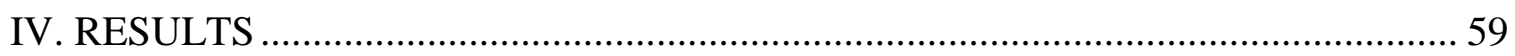

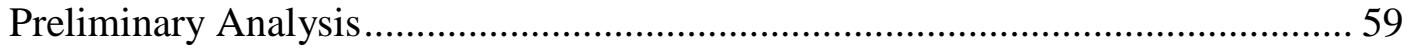

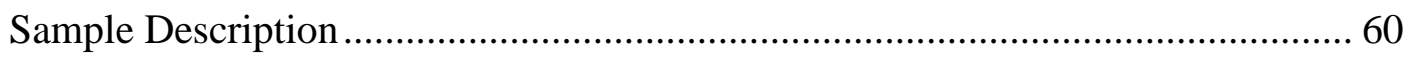

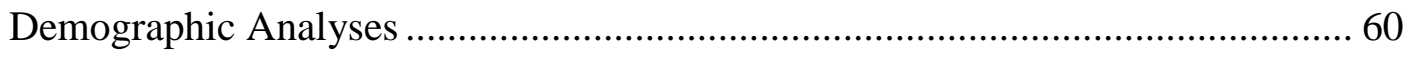

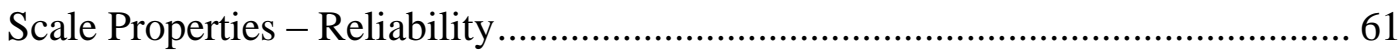

Descriptive Statistical Analysis of JSS Scale .............................................. 63

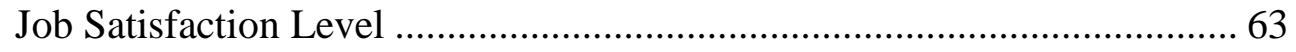

Contribution of Demographic Factors ................................................ 66

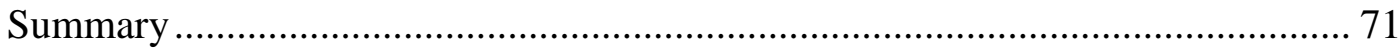

V. SUMMARY, DISCUSSION, AND RECOMMENDATIONS ............................. 73

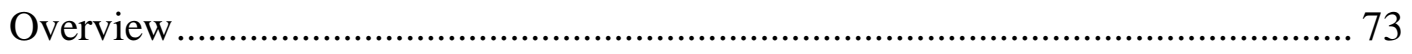

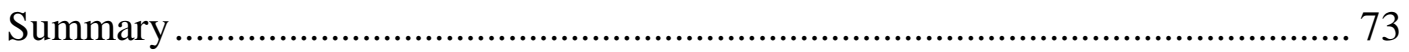

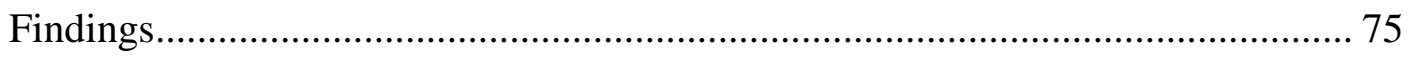

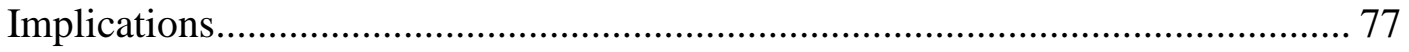


Discussion

Recommendations for Future Research ..................................................... 83

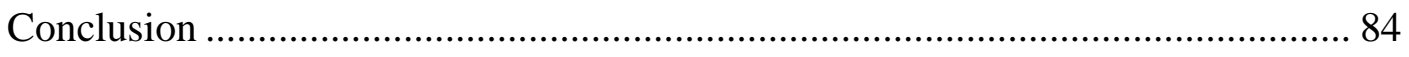

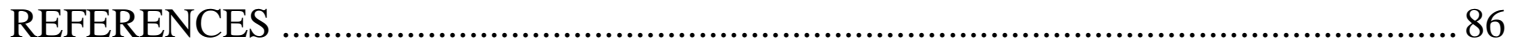

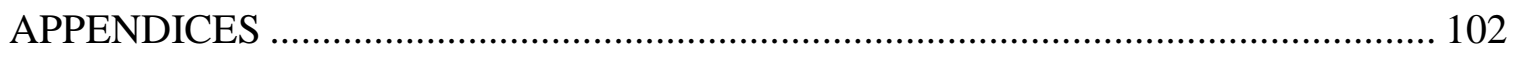

APPENDIX A. QUESTIONNAIRE ..................................................... 103

APPENDIX B. DESCRIPTION OF EXPERT PANEL ................................ 107

APPENDIX C. PROFESSIONAL COMMENT FORM ................................. 108

APPENDIX D. STUDENT COMMENT FORM ........................................ 109

APPENDIX E. IRB APPROVAL ........................................................... 110

APPENDIX F. COVER LETTER - FIRST MAILING ................................ 111

APPENDIX G. POST CARD - SECOND MAILING .................................. 112

APPENDIX H. COVER LETTER - THIRD MAILING ............................... 113

APPENDIX I. SUMMARY OF PARTICIPANT RESPONSES TO JOB

SATISFACTION SURVEY .............................................................. 114 


\section{LIST OF TABLES}

Table

Page

1. Summary of Campus Recreation Administrator's Job Duties and Responsibilities 31

2. Summary of Facets Used in the Job Satisfaction Survey (JSS) 49

3. Job Satisfaction Survey (JSS) Scoring Guide and Internal Consistency Reliability 54

4. Job Satisfaction Norms: Total Americans ......................................................... 56

5. Demographic Characteristics of Campus Recreation Administrators $(N=104)$

6. Cronbach's Alpha Coefficients for Campus Recreation Administrators and Spector's Respondents

7. Descriptive Statistics for Campus Recreation Administrators $(N=104)$ and

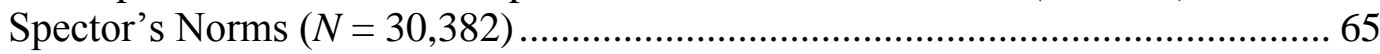

8. Interpreting the Correlation Coefficients (Magnitude of Relationship) ............... 67

9. Spearman Correlation Coefficients of Independent Variables ............................ 68

10. The Coefficients for the Regression Model .................................................. 69

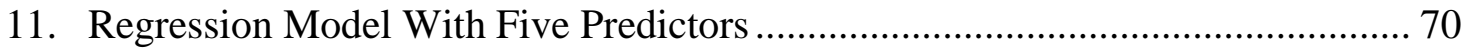

12. Model Summary to Predict Job Satisfaction.................................................. 71 


\section{CHAPTER I}

\section{OVERVIEW}

This chapter of the dissertation presents the background of the study, specifies the problem of the study, lists the research questions, describes the significance, and presents an overview of the methodology used. The chapter concludes by noting the limitations of the study and defining key terms.

\section{Background of the Problem}

Over the years, higher education has experienced a major transformation in its overall complexity, diversity, and significance. Universities and colleges have had to adapt to a variety of issues and conditions that require higher education administrators to be innovative and resourceful when developing strategies that increase academic achievement and student learning. In order to balance internal and external pressures for student learning strategies it has become important that higher education administrators continue to explore what academic and administrative functions impact students on a university and college campus. Given these expectations for student learning, higher education administrators have developed, maintained, and enhanced institutional quality and effectiveness. Having administrators identify and evaluate what institutional programs and services create a social and intellectual environment for students helps to build a successful institutional climate and culture. 
Higher education institutions of all types and sizes are being encouraged to be diverse, to be accessible, and to offer quality programs in order to meet the needs and wants of their faculty, staff, and students (Birnbaum, 1988; Culp, 2005; Massey, 2001). Although differences are evident between public and private universities, institutions still must encourage all departments on campus to better their programs and improve effectiveness and help build awareness and pride among those connected to the university and college. Having a thorough understanding of how higher education administrators function helps universities and colleges identify what departmental programs and services have the greatest amount of influence on the overall productivity of the college campus.

One of the largest and most rapid areas of growth and influence in higher education is student affairs (Astin, 1997). Student affairs professionals create an environment that supports learning, promotes healthy lifestyles, builds leadership skills, fosters career development, and enhances personal growth (Zhao \& Kuh, 2004). The student affairs profession provides an opportunity to balance the physical, emotional, spiritual, and social well-being of students. Student affairs professionals are committed to building a sense of community through participation in student organizations, community service, and campus recreation. These principles of the student affairs profession are critical when supporting the mission and objectives of the institution and exist so that they can enrich the education of students (American Association of Higher Education, American College Personnel Association, \& National Association of College Personnel Administrators, 1998).

One area of the student affairs profession that has emerged as a significant institutional program is campus recreation (Belch, Gebel, \& Maas, 2001; S. C. Brown, 
1998; Lindsey \& Sessoms, 2006). University and college administrators are increasingly aware that campus recreation is one of the most dynamic and fastest-growing services on a college. The campus recreation profession has a responsibility to be attentive to the programs and services they offer and the professional skills they possess (Garland \& Grace, 1993; Osman, Cole, \& Vessell, 2006; Young \& Ross, 1998). Campus recreation administrators have an obligation to show they are competent in their leadership abilities, skills, and knowledge base in order to serve their participants and their institution effectively.

\section{Statement of the Problem}

The ability of campus recreation administrators to be leaders on campus and develop working partnerships with other members of the campus community requires them to be able to plan, guide, and lead their institutions towards the development of student learning. Campus recreation administrators need to be able to address student needs, design successful programs and services, and develop effective policies. Being a leader on campus provides campus recreation administrations the opportunity to foster an affirming and enriching campus environment that can be valuable to the college community and student development.

Recently, campus recreation has been used as an important recruitment and retention tool. Belch et al. (2001), S. C. Brown (1998), Lindsey and Sessoms (2006), and Osman et al. (2006) pointed out that campus recreation programs are an essential recruitment and retention tool that impacts participant's satisfaction and increases one's intention to participate on a consistent basis. According to Reynolds (2007), institutional characteristics, facilities, and programs have a direct correlation with a student's decision 
and intention to attend college. Because campus recreation has the opportunity to attract and retain students and support their students' academic success, they are seen as an effective component in the recruitment and retention initiative (Bryant, Banta, \& Bradley, 1995; Moore \& Marsh, 2007). Therefore, it is essential that higher education administration include campus recreation in their recruitment and retention strategies.

Studying job satisfaction allows campus recreation administrators to identify what long-established institutional behaviors and actions give them satisfaction. Satisfaction in the workplace should instill a positive work environment and continue to impede adaptability and positive change (Sopow, 2006). If campus recreation administrators are to assume responsibility for managing their work environment, further research is needed to assess the impact a campus recreation administrator's work environment has upon their satisfaction with the job.

\section{Research Questions}

This dissertation was designed to examine the perceived job satisfaction of campus recreation administrators at 4-year institutions. The following research questions were addressed:

1. To what degree do campus recreation administrators at 4-year institutions express their job satisfaction?

2. Do gender, age, institutional size, type of institution, and years of experience explain the overall level of job satisfaction?

Null hypothesis: Gender, age, institutional size, and years of experience of campus recreation administrators do not significantly predict job satisfaction. 
1. The dependent variable(s) in this study were the measure of overall job satisfaction and the nine sub facets of job satisfaction. The independent variables in this study were gender, age, institutional size, and years of experience.

\section{Professional Significance of the Study}

The rationale for conducting this study was a lack of research regarding what affects job satisfaction of campus recreation administrators at 4-year institutions. Research is also needed to study whether demographic variables such as gender, age, institutional size, and years of experience explain the overall level of job satisfaction among campus recreation administrators.

Studying job satisfaction enables campus recreation administrators to identify what long-established institutional behaviors and actions may give them job satisfaction. If campus recreation administrators are to manage their personal work environment and job satisfaction, they need a method in which it may be measured. This study allows campus recreation administrators to examine the concept of job satisfaction.

Although the concept of job satisfaction is not new, little research has addressed job satisfaction of campus recreation administrators. A study done by Zhang, DeMichele, and Connaughton (2004) is the only research that specifically investigated and addressed job satisfaction of campus recreation administrators. The study evaluated two dimensions, "satisfaction with organizational work environment" and "satisfaction with individual work environment." These dimensions were assessed through the use of the Scale for Campus Recreation Administrator Satisfaction (SCRAS). Although this scale 
went through rigorous testing procedures, the scale has only been used once and is still in its exploratory stage (Zhang et al.).

This study was designed to advance the study of Zhang et al. (2004) by specifically looking at job satisfaction of campus recreation administrators at 4-year public and private universities and colleges. Further, this study attempts to determine whether certain demographics such as age, gender, institutional size, institutional type, and years of experience in the campus recreation profession predict a campus recreation administrator's job satisfaction. As campus recreation continues to become an important component of higher education institutions, there is a need to study those demographic variables associated with job satisfaction of campus recreation administrators.

Overview of the Methodology

This study examined research questions through the quantitative survey research method. The target population was campus recreation administrators from 4-year higher education institutions. The research design for this study investigated the perceived levels of job satisfaction among campus recreation administrators. Participants were selected based on their affiliation with the National Intramural Recreational Sports Association (NIRSA) which encompasses all geographical regions in the United States.

Based on a comprehensive review of a campus recreation administrator's position and review of the literature on higher education, campus recreation, and job satisfaction, the Job Satisfaction Survey (JSS) was identified as an appropriate instrument. It is believed that the Job Satisfaction Survey, developed by Spector (1985) and used in 29 previous studies $(N=3,690)$, would provide evidence of the relationship that exists between job satisfaction and the job tasks of campus recreation administrators. The JSS 
consists of nine subscale measures that relate to employee job satisfaction and strongly examines perceptual and attitudinal variables. These nine factors include satisfaction with pay, promotional opportunities, fringe benefits, contingent rewards, supervision, coworkers, nature of work itself, communication, and work conditions.

\section{Limitations of the Study}

This study was limited by the following factors:

1. A perceptual and attitudinal scale was used by the researcher to measure job satisfaction in the study. Opinions and perceptions of campus recreation administrators may change with time and may be affected by non-work variables. In addition, an employee's work environment, individual responsibilities, and positions may change. Therefore, levels of job satisfaction may change.

2. Findings are based on self-reported responses to the Job Satisfaction Survey and, therefore, rely on the accurate self-assessment, honesty, and motivation of responders. Accuracy has not been validated by other independent measures.

3. Testing job satisfaction over an extended period of time would have addressed potential problems related to bias. However, the cost and time needed to undertake such a study would be prohibitive to the completion of this study.

\section{Definition of the Terms}

For the purpose of this study, the following terms are defined to provide a common understanding throughout this dissertation: 
1. Campus recreation. Campus recreation, often referred to as recreational sports or intramurals, can be described as a broad spectrum of co-curricular activities that encompass sports and other physically active pursuits. Campus recreation includes the programming of any on or off campus program, activity, or event that relates to the well-being of any student, faculty, or staff member at a university or college (Byl, 2002; Ellis, Compton, Tyson, \& Bohlig, 2002; Haines, 2001; Mueller \& Reznik, 1979).

2. Campus recreation administrator. The campus recreation administrator is responsible for the administration, promotion, and financial considerations concerning a university or college campus recreation program.

3. Institutional size. This term refers to the number of full-time employees responsible for providing campus recreation programs and services.

4. Job satisfaction. Job satisfaction refers to the extent individuals enjoy their job and job experiences.

5. Job satisfaction subscales. The word subscale is also synonymous with dimensions, factors, facets, and variables. Job satisfaction subscales are involved when studying job satisfaction within an institution. Those subscales used in this study include: Pay, Promotion, Supervision, Fringe Benefits, Contingent Rewards (performance based rewards), Operating Procedures (required rules and procedures), Coworkers, Nature of Work, and Communication.

5. Student Services. Student services are offered by a college's division of student affairs that is responsible for out-of-classroom learning and 
experiences. Student services are designed to create an environment where interaction occurs between students, faculty, staff, and the university community. Some of the programs and services offered by a college's division of student affairs are career development, student activities, counseling and support programs, community outreach, and campus recreation (Hamrick, Evans, \& Schuh, 2002). 


\section{CHAPTER II}

\section{REVIEW OF THE LITERATURE}

\section{Overview}

This chapter explores the campus recreation profession and examines to what degree campus recreation administrators at 4-year public and private institutions express their job satisfaction. The chapter begins by examining the structure of higher education and introducing the importance of the student affairs profession. Next, the campus recreation profession is presented and an overview is provided. Additional research explores the purpose of campus recreation, how campus recreation is defined, and its importance to a university and college campus, followed by an examination of campus recreation administrators. Finally, research on job satisfaction is presented to provide a theoretical understanding of the variables involved when studying job satisfaction and the campus recreation profession.

\section{Introduction}

Universities for many years have contributed to the development of an affluent and competitive knowledge-based community. Bok (2003), Couturier (2005), and Duderstadt (2000) explained that universities and colleges play an extremely effective and important role in the economic, social, and cultural development of this quickly changing world. George (2006) explained that universities and colleges are considered more than academics; they add to the physical and aesthetic appeal of a community; the 
diversity of residents; and the arts, culture, and entertainment milieu. A number of underlining principles and characteristics affect the make-up of an institution and its members. In response to these influences, it is necessary for university and college administrators to review what they do and how they do it.

Higher education has seen a major transformation in regards to its overall scope and significance. Over the years, higher education experienced a dramatic increase in its complexity and diversity (Eckel \& Kezar, 2003; Kezar, 1999). Due to increasingly diverse populations, new demands for accountability, and changes in the public view toward education, there is evidence that postsecondary education has experienced radical change (J. L. Anderson, 2005; Duryea, 2000; Foote, 1999). Bleiklie and Powell (2005) stated that "there are pressures for greater productivity and efficiency, demands for more responsiveness, and enhanced application for university personnel” (p. 1). Eckel and Kezar (2003) explained that these demands and changes, if managed and implemented appropriately, have the opportunity to positively affect the degree of influence higher education administrators have on its programs, services, and employees.

What is consuming a fair amount of attention in the research is the changing nature of higher education administration. It has become increasingly important that higher education administrators continue to explore and assess the impact students, faculty and staff, and administrators have on a university and college campus. Higher education administrators have seen the need to introduce, implement, and evaluate new trends and forces that affect programs and services, departments and colleges, and employees. Higher education administrators continuously must develop new ideas, 
improve their services, and enhance program offerings so that higher education remains successful (Wald, 2000).

\section{Institutional Type}

Each type of institution has a repertoire of characteristics that define "who they are" and the various roles and contexts that give them identity (Kreiner \& Ashforth, 2004; Pratt \& Foreman, 2000; Serpe, 1987). Universities and colleges need to be accountable to their goals and purposes, institutional climate and culture, governance structures, decision making, and extent of participation towards change (Dill, 1984). Universities and colleges of all types and sizes are encouraged to be diverse, be accessible, and offer quality programs in order to meet the needs and wants of their faculty, staff, and students (Birnbaum, 1988; Culp, 2005; Massey, 2001).

One way to characterize institutions is public and private. Public and private institutions of higher education are longstanding identities. The conventional language of public and private institutions in higher education, in most research, is designed for identification and classification purposes. However, for this review it is meant for explanation and simple analysis of higher education administration.

In the United States, public institutions are described as important centers that excel in research, service, and instruction. The role of public universities is to focus on research and attend to the broad educational needs of its members (Wilkerson \& Yussof, 2005). According to Ehrenberg (2007), "Roughly two-thirds of all four-year college students and four-fifths of all college students (including community-college students) attend public higher-education institutions" (p. 47). 
Currently, public universities tend to be more directly accessible to public policy makers who allow government more control over the operation and production of its functions (Crow, 2007; Scott, Bailey, \& Kienzl, 2006). One major characteristic of public institutions is that they are founded and operated by state government entities (Calhoun, 1998). In recent years the state support of public universities has been declining, forcing many public universities to become more dependent on tuition and external fundraising (Carbone \& Winston, 2004; Scott et al., 2006; Volkwein \& Malik, 1997).

Private institutions have become vital to the growing and diverse student population of higher education (Bullock, 2005). Private universities have the privilege of enhancing the quality of program and service offerings by increasing competition amongst educational providers (Wilkinson \& Yussof, 2005). One major characteristic of private institutions is that they are not financially dependent upon the government. Universities operating in the private sector are given greater autonomy from the state and are permitted to set their own budgets, salaries, and tuition rates. Lipka (2005) stated that "private universities are given the opportunity to work aggressively to acquire big gifts from donors, to win government and corporate research grants, and to mount large-scale capital campaigns to increase their endowments" (p. 1).

Although differences are evident between public and private universities, the type of institution does not necessarily equate to a higher quality education (Pascarella \& Terenzini, 1991, 2005; Strauss \& Volkwein, 2002, 2004). In fact, studies by Pascarella and Terenzini suggested that the difference between the administrative operation of public and private universities and colleges provides competition and encourages all institutions to better their programs, improve institutional effectiveness, and improve 
quality of provisions. Amey (2006) and Bleiklie and Powell (2005) indicated a major step in understanding how higher education administration functions is to identify what departmental programs and services have the greatest amount of influence.

On a university and college campus there are many programs and services that provide an outside-the-classroom experience to students, faculty, and administration. One area that has emerged as one of the top institutional services is student affairs. The student affairs profession provides the opportunity to balance the physical, emotional, spiritual, and social well-being of its participants. The student affairs profession encourages that its professionals respect individual differences and be committed to focusing their strengths and knowledge to enhance the development of students (Hunter \& Murray, 2007). Student affairs professionals have an obligation to expand their body of professional knowledge and expertise and to further develop skills through professional education and experience (Hirt, 2007). The student affairs profession is committed to building a sense of community through participation in student organizations and community service.

The demand for student affairs programs and services offered on university and college campuses encourages the student affairs profession to address the need for program and service quality and student learning (Hirt, 2007; Lewis, Barcelona, \& Jones, 2001; Osman et al., 2006). These expectations for student learning involve all types and sizes of institutions which strongly affect the delivery of many student affairs programs and services. One area of the student affairs profession that has gained popularity is campus recreation. 
Campus recreation has become a necessary asset to universities and colleges. The campus recreation profession has an obligation to focus on the roles and responsibilities they have with their university or college, because they need to show they are competent in their leadership abilities, skills, and knowledge base in order to serve their participants and their institution effectively. Campus recreation administrators must work effectively and efficiently and not be overwhelmed by institutional and administrative factors that they cannot control (Schneider, Stier, Kampf, Wilding, \& Haines, 2007; Zhang et al., 2004). Additionally, Young and Ross (1998) indicated that campus recreation administrators, as have all student affairs professionals, experienced an increase of workload, responsibilities, and mounting expectations while still being required to offer a successful product. Weese (1997) explained that if campus recreation administrators want their programs and services to survive in a competitive market then they must ensure that their program offerings are expertly conceived, promoted, staged, and evaluated.

Limited research exists that has investigated the impact of campus recreation programs and services on different types of institutions, specifically research studying the degree to which campus recreation administrators are satisfied with their job. Higher education administrators have had to acknowledge the importance of analyzing the campus recreation work environment. Higher education administrators realize that campus recreation is not just a component of student affairs, but an important tool that helps develop the overall makeup of the institution (Cooper \& Faircloth, 2006).

Student Affairs and the Co-Curricular Learning Environment College is a potentially transforming experience that challenges students to examine their previous ways of thinking and behaving. The college environment is 
structured in order to promote learning and educate students (Tinto, 1997, 2000). In terms of educating students, Astin $(1991,1995)$ found that:

A college environment fosters a high level of verbal and mathematical skills; develops an in-depth understanding of social, cultural, and political institutions; facilitates one's ability to think reflectively, analytically, critically, synthetically, and evaluatively; develops one's value structures and moral sensibilities; facilitates personal growth and self-identity; and fosters one's sense of career identity and vocational competence. (p. 1)

The student affairs profession plays an important role within the education process. The profession is concerned with attaining educational goals, developing values that contribute to the student's quality of life, and providing quality programs and services that facilitate student development (Hayek \& Kuh, 2004).

Student affairs professionals have significant impact on student development and learning outside of the classroom. Over the years the student affairs profession has increased its influence and presence on university and college campuses (Bair \& Associates, 1998; Hirt \& Creamer, 1998; Woodard, 1998). Within postsecondary education, the student affairs profession has transformed that influence and presence into "greater productivity and efficiency, increased responsiveness, and enhanced application for university personnel” (Bleiklie \& Powell, 2005, p. 1). Kuk, Cobb, and Forrest (2007) stressed that "issues regarding changing demographics, shifting economic conditions, increasing accountability, quantifying quality assurance, and demonstrating organizational effectiveness" required institutions to take different approaches to understand the profession (p. 668). Because the student affairs profession is an influential stakeholder on university and college campuses, Evans and Williams (1998) proposed:

Student affairs practitioners be prepared to engage in an ever increasing range of activities including: facilitating student and staff development, collaborating with faculty, enhancing learning environments for students, contributing to the 
academic mission, creating multiculturally sensitive environments, being change agents, plus using sound management and administrative practices. (p. 105)

The aforementioned activities require student affairs professionals to intentionally integrate student development theory into their programs and services and actively prepare for institutional change (Evans \& Phelps Tobin, 1998).

\section{Principles That Guide Student Affairs Work}

One topic that has received considerable attention in higher education is student engagement (Kuh, 2001, 2003; Pascarella \& Terenzini, 2005). The commitment to involve students in educationally purposeful activities can be traced back to the 1980s when discussions of best practices in student affairs occurred (Hamrick et al., 2002). According to Walter and Eodice (2005), three main documents were created to promote student learning and engagement initiatives: The Student Learning Imperative (American College Personnel Association, 1996); Powerful Partnerships: A Shared Responsibility for Learning (Joint Task Force on Student Learning, 1998); and the Principles of Good Practice for Student Affairs (ACPA \& NASPA, 1997). Each of these documents identifies the development of student affairs programs that support student learning as a goal for best practice. The documents are discussed in detail in the paragraphs that follow.

\section{Student Learning Imperative}

Student affairs professionals have much to offer when it comes to enhancing student learning through engagement. According to the Student Learning Imperative (SLI) 'the concepts of 'learning,' 'personal development,' and 'student development' are inextricably intertwined and inseparable" (ACPA, 1996, p. 1). These terms are used interchangeably throughout the SLI in order to explain the intent of student learning both 
inside and outside of the classroom. The SLI was written to encourage student affairs professionals to intentionally focus on the scope and nature of student learning and development in an effort to gain a clearer understanding of its connection to overall student success. Hunter and Murray (2007) explained that the SLI suggests student affairs professionals are educators too. Student affairs professionals share the responsibility of creating conditions in which students engage in purposeful activities. This shared responsibility brings about many different possibilities that emphasize the need to enhance student learning.

Powerful Partnerships

A second document that has the same view of shared responsibility as the SLI report is Powerful Partnerships: A Shared Responsibility for Learning (Joint Task Force on Student Learning, 1998). The Powerful Partnerships report promotes the idea that when everyone on campus, particularly student affairs professionals, shares the responsibility for student learning there can be high expectations for student growth and development. One way is for student affairs professionals to develop working partnerships and collaborate with other members of the university community (Hunter \& Murray, 2007). These types of partnerships help foster an affirming and enriching campus environment between faculty and staff. Additionally, these partnerships help develop service learning opportunities that strengthen change and growth within the student.

Principles of Good Practice

The third document, Principles of Good Practice for Student Affairs (ACPA \& NASPA, 1997), reminds the student affairs profession that good practice must be 
considered within the contexts of work. The principles of good practice provide a framework to fulfill the commitment to the education of students and institutional effectiveness. Blimling (2001) suggested student affairs professionals are given an important role of engaging student learners through active learning processes that create knowledge acquisition, skill development, and personal growth. Blimling and Whitt (1999) promoted that the principles were designed to be incorporated into the daily work of student affairs professionals to shape their responsibilities, communicate their purpose, and affect their interaction with students. These principles are intended to help student affairs professionals create learning-oriented student affairs divisions and consider the ways in which they shape good practice across institutions. Clearly the principles were intended as a guide for assessing contributions to student learning and for examining and implementing the profession's missions, policies, programs, and services (ACPA \& NASPA, 1997).

Seven Principles

In addition to The Student Learning Imperative, Powerful Partnerships: A Shared Responsibility for Learning, and Principles of Good Practice for Student Affairs, Chickering and Gamson’s (1987) landmark publication, Seven Principles of Good Practice in Undergraduate Education, provides insight for enhancing student learning and development. The authors introduced seven categories that directly influence student learning and the quality of their overall educational experiences. In general these categories focus on the thought that the more students are engaged in the learning process the more likely they are to persist and graduate from college. 
There is a positive connection between Chickering and Gamson's (1987) research and Astin's (1984) theory of involvement. Astin's theory suggests students learn more when they are involved in both the academic and social aspects of the collegiate experience. In general, students who are involved "devote significant energy to academics, spend time on campus, participate actively in student organizations and activities, and interact often with faculty" (Hunt, 2003, p. 134). Both the Seven Principles of Good Practice in Undergraduate Education and Astin's theory of involvement assist student affairs professionals in meeting the needs of the students and they help align the student affairs profession more closely with an institution's overall goals and mission (Chickering \& Gamson, 1991; Kuh, 2001, 2003).

\section{Student Engagement}

As is evident from the preceding sections, The Student Learning Imperative, Powerful Partnerships, and the Principles of Good Practice for Student Affairs promote student learning and engagement initiatives. These documents are important because they act as guides for the student affairs profession providing insight about student learning and engagement. To learn how student affairs professionals can enhance student success, student engagement data must be gathered and converted into action (Hayek \& Kuh, 2004). One way to obtain this information is through the National Survey of Student Engagement (NSSE).

The NSSE is a national survey and research project that supports the argument for purposeful student engagement and student affairs work. The NSSE was designed to demonstrate how and where students are engaged on a college or university campus. A survey instrument that is designed to investigate undergraduate educational experiences, 
student involvement, and institutional practice in numerous areas, NSSE relates particular activities and practices to high-quality undergraduate student outcomes (NSSE, 2000). For example, Kuh (2000) suggested that "administrators and faculty members can use their NSSE results to discover patterns of student-faculty interactions and the frequency of student participation in other educational practices that they can influence directly and indirectly to improve student learning" (Kuh, 2001, p. 2).

The NSSE is used to help identify those areas of student performance and institutional practices that, if improved, may enhance the overall quality of the student experience (Carini, Klein, \& Kuh, 2006; Ewell \& Jones, 1996). Additionally, the NSSE summarizes key concepts associated with those institutional factors that add shape and value to academic, interpersonal, and extracurricular offerings to enhance student and institutional performance (Kuh, 2001, 2003). For example the NSSE reports the frequency with which students engage in dozens of co-curricular activities and programs that signify them taking advantage of learning opportunities that are offered inside and outside of the classroom (Kuh, 2001). Through collaborative ventures with academic affairs, student affairs professionals have initiated assessment and improvement efforts, particularly around first-year experience initiatives (NSSE, 2000). The student affairs profession evaluates NSSE results and then identifies whether a particular campus offers the kinds of programs, services, experiences, and opportunities that are known to benefit students.

Given the changing nature of higher education and the diverse needs of students accessing higher education, scholars (Kuh, 2003; Pascarella \&Terenzini, 2005) believe a campus environment can be a key contributor to a students learning and to the 
development of social, educational, intellectual, and recreational interaction. Zhao and Kuh (2004) found that students who actively participate in various out-of-class activities are more likely to connect with their environment which can be important for student retention, success, and personal development. In addition, Zhao and Kuh explained that many campus environments encourage involvement in academic and social activities that extend beyond the classroom. Such approaches are linked with positive behaviors including academic achievement and an increased level of student involvement on campus.

Moreover, data from The U.S. Department of Education's Study Group on Conditions of Excellence in American Higher Education (1984) showed student learning was successfully accomplished when students were actively involved in the learning process, high expectations were placed on the students, and assessment and feedback was provided. Similarly, Hunter and Murray (2007) asserted that support provided by faculty as well as student affairs in the learning process encourages students in their development. Creating an environment where faculty and student affairs work together generates significant social environments that have a positive influence on student development (Blake, 2007).

Blake (2007) suggested that "for ultimate success in student development the student affairs profession needs to develop their services and programming around the student" (p. 65). Senior level leaders and administrators view the student affairs profession as facilitators of student growth and development through programs and services (Astin, 1993, 1997; Pascarella \& Terenzini, 2005). The student affairs profession supports student development by offering a broad array of programs and services (Hirt, 
2007). Research (Miller, Bender, Schuh, \& Associates, 2005) shows those programs and services offered by a college's division of student affairs promote learning and development in areas such as career development, student activities, counseling and support programs, community outreach, and campus recreation. Thus, the student affairs profession provides a full range of services and programs that continually assist students in identifying, clarifying and maximizing their personal, educational, and career goals.

Student affairs professionals, according to Astin (1997), have the unique privilege of being able to undertake activities directly affecting students' attitudes, abilities, and quality of life. Hunter and Murray (2007) suggested student affairs professionals have an obligation to focus their strengths and knowledge of student development to enhance student success, involvement, and retention. Blake (2007) also stated "student affairs professionals play major roles in increasing academic achievement, student learning, and retention" (p. 65). Likewise, Kuh, Buckley, and Kinzie (2007) believed that one direct way student affairs professionals affect students is by "intentionally designing programs and practices that channel student behavior into educational purposeful activities" (p. 79). With the growing number of student affairs program and service opportunities available on campus, student affairs professionals have a powerful influence on student learning and development.

\section{Campus Recreation}

As discussed in the preceding sections, within the past decade, student affairs work has become an influential and valuable tool to integrate and involve students in college life (Dalgarn, 2001; Evans et al., 1998). According to Reynolds (2007), institutional characteristics and facilities have a direct correlation with a student's 
decision to attend various institutional types. Factors such as an attractive campus, facilities, academic programs, and student programs and services play a key role in the decision process for students. Because student affairs professionals have the opportunity to attract and retain students and support their students' academic success, they may be seen as an effective component of recruitment and retention (Bryant et al., 1995; Moore \& Marsh, 2007).

One area within the student affairs profession that has emerged as an important recruitment and retention tool is campus recreation (Belch et al., 2001; S. C. Brown, 1998; Hunter \& Murray, 2007; Lindsey \& Sessoms, 2006; Osman et al., 2006; Zhang et al., 2004). Campus recreation reflects the values and principles of the student affairs profession (Osman et al., 2006). Campus recreation provides participants with the opportunity to learn new skills or practice an existing skill. It allows for the enhancement of social skills, and the development of personal character, leadership, and sportsmanship (Byl, 2002). Campus recreation is not just a fundamental building block for achieving specific educational goals and objectives of the institution, but also an opportunity to teach those valuable life lessons that cannot be learned in the typical college classroom (Dalgarn, 2001). Haines (2001) also investigated the benefits of campus recreation programs and services and found that when students participate in recreational sports they experience feelings of physical well-being, sense of accomplishment, improved fitness, enhanced physical strength, and reduced stress levels - all of which facilitate the development of students.

Kovac and Beck (1997) reported that involvement in recreational sport activities leads to high levels of satisfaction with life and college experiences. Prior research by 
Banta, Bradley, and Bryant (1991) indicated that 30\% of the students at six different universities who took the National Intramural-Recreational Sports Associations' Quality and Importance of Recreational Sports instrument indicated that the quantity and quality of campus recreation programs were important factors in their decision to attend a university or college. A study by Bryant et al. (1995) found that $95 \%$ of the student respondents engaged in some form of leisure and recreational activity several times per week, and of those respondents, $20 \%$ reported they were more likely to participate in campus recreation programs than any other campus activity available on campus.

Kovac and Beck (1997) also investigated the importance of campus recreation on university and college campuses. Their findings showed that students were generally satisfied with their recreational sport experiences. Their results showed that because of the campus recreation programs offered, students were more likely to attend and continue at that institution. Additionally, participation in campus recreation supported the idea that the higher a student's satisfaction was with his or her campus recreation experiences resulted in a higher satisfaction in all aspects of campus life.

\section{Defining Campus Recreation}

Campus recreation, often referred to as recreational sports or intramurals, can be described as a broad spectrum of extracurricular activities that encompass sports and other physically active pursuits. According to Mull, Bayless, Ross, and Jamieson (1997), campus recreation is defined as "programming of sport activity for fitness and fun" (p. 2). Byl (2002), Ellis et al. (2002), Haines (2001), and Mueller and Reznik (1979) described campus recreation as a method of programming any on or off campus program, activity, or event that relates to the well-being of any student, faculty, or staff member at a 
university or college. Lewis et al. (1998) indicated that campus recreation originally was intended to provide students the opportunity to participate in various types of sport programming.

Since Princeton University held the first intramural event, campus recreation has gone through numerous changes (Lewis et al., 1998). The campus recreation arena is more than just intramurals and sports activities. Recently, many recreational programs have expanded their offerings to include: (a) special events on and off campus; (b) leadership development programs; (c) competitive sporting events for their intramural teams that involve regional, state, and national competitions; (d) club sports; (e) fitness programming; and (f) informal recreation (S. C. Brown, 1998; Lewis et al., 1998). In addition to these new types of programs and service offerings, campus recreation has seen the age range of its participants change. No longer is campus recreation just for the student, but it is now available to faculty, staff, and the community who have different levels of ability and interests.

The National Intramural Recreational Sports Association (NIRSA), the guiding professional organization of campus recreation, plays an integral part in the development of programming on university and college campuses. NIRSA is committed to the development of quality recreational programs, facilities, and services for diverse populations on university and college campuses. NIRSA for many years has proven to be fundamental to the success of campus recreation. Campus recreation is no longer an option on college and university campuses, but now is aligned with the overall mission of a university and college (Cooper \& Faircloth, 2006; Weese, 1997). 
Research has shown campus recreation as a valued opportunity to provide a balance between academics and spare time; improve physical, mental, and emotional health; and serve as a pathway toward individual personal growth and well-being (Broughton \& Griffin, 1994; Dalgarn, 2001; Ellis et al., 2002; Haines, 2001). Broughton and Griffin (1994) pointed out that participation is a fundamental principle that guides the consumer to life-long learning and enjoyment of their leisure time. Weese (1997) suggested that campus recreation programs exist "to educate the student, enhance the quality of student life, and prepare people for the future" (p. 264).

\section{Purpose of Campus Recreation}

Campus recreation can be viewed as an appropriate medium to satisfy a broad spectrum of leisure and recreational needs (Carlton \& Stinson, 1986; Lewis et al., 2001; Osman et al., 2006; Weese, 1997). Many student affairs professionals agree that involvement in a leisure activity or program is an important influence and force that shapes the lives of college students (Astin, 1993; Culp, 2005; Helfgot, 2005). Participation in a leisure pursuit or activity serves as a means to improve one's wellbeing, enhance relationships, and express oneself. Additionally, leisure participation provides the opportunity for relaxation, reflection, renewal, release, and restoration (Edginton, DeGraaf, Dieser, \& Edginton, 2002). As Edginton et al. wrote:

Leisure is woven into the fabric of our society and culture ... We seek leisure as a way of uplifting the spirit, improving our well-being, and enhancing our relationships with others. Leisure is a powerful force that helps shape our own sense of self-worth, assists in the formulation and communication of values and norms, and aids us in improving the livability of our lives and our communities. For many, leisure is a perfect gift ... Through leisure individuals find opportunities to express themselves in ways that are not possible in life's other venues. (p. XII) 
For college students seeking to become actively involved, the challenge is deciding what opportunities are available to fulfill their demand for participation. Bresciani, Zelna, and Anderson (2004) suggested that students participate in programs linked to positive outcomes. Broughton and Griffin (1994) found that students want to be engaged, and when student affairs professionals provide those leisure opportunities it enables them to enhance their overall educational experience. According to Osman et al. (2006), students need leisure opportunities to develop their sense of competency, to develop connections with others, give them some degree of autonomy, and provide opportunities for originality and self-expression. Participation in some form of leisure is positively related to student success and leads to positive perceptions of their social environment (Zhao \& Kuh, 2004). By offering leisure opportunities, student affairs professionals are able to enhance the students' leisure experience on all types and sizes of university and college campuses.

Campus recreation is rapidly developing into an indispensable component of the student affairs profession in which every individual has the opportunity to enjoy during leisure time (Osman et al., 2006). Lewis et al. (1998) stated that "campus recreation programs are at the core of almost all leisure and recreation programs offered in public and private, non-profit and for-profit, college and university, and employee service recreation settings" (p. 72). The demand for campus recreation on university and college campuses encourages student affairs professionals to meet students' needs (Lewis et al., 2001; Osman et al., 2006). Being able to offer exciting, accessible, and innovative exciting programs and activities that encourage students, faculty, and staff to become more actively involved in their personal well-being is a fundamental building block of the 
campus recreation profession (Byl, 2002; Ellis et al., 2002; Haines, 2001; Mull et al., 1997; Young \& Ross, 1998).

\section{Campus Recreation Administrators}

A number of studies have shown that campus recreation administrators face overwhelming challenges in meeting the demands of an increasingly diverse student body (Bleiklie \& Powell, 2005; Bok, 2003, Couturier, 2005; Duderstadt, 2000). As campus recreation administrators recognize the significance of creating social environments they will be expected to play key roles in the transformation of the campus environment. Given these expectations it is important that higher education administrators hire campus recreation administrators that support a social environment that focuses on academic achievement and student development (Blake, 2007).

S. C. Brown (1998) and Cooper and Faircloth (2006) suggested that in order for campus recreation departments to function effectively, universities and colleges must hire qualified campus recreation administrators. Within most campus recreation departments, a campus recreation administrator is employed to meet the demands of the participants. Campus recreation administrators are part of the education process that is concerned with attaining educational goals, the development of values that contribute to student development, and providing assistance in recruitment and retention of students and faculty (S. C. Brown, 1998; Cooper \& Faircloth, 2006; Hall, 2006).

Campus recreation administrators are an important asset to universities and colleges because they offer the kind of leadership that will provide opportunities for positive learning and development (Taylor, Canning, Brailsford, \& Rokosz, 2003). According to Walter and Eodice (2005), the campus recreation profession uses student 
learning and engagement initiatives to provide direction for the profession. Integrating these initiatives permits campus recreation administrators more effective interaction with students (Blake, 2007). Gappa, Austin, and Trice (2005) noted that at many institutions, campus recreation has been used by higher education administration as a service that can help form a positive university or college identity, increase resources, and increase retention of students. S. C. Brown (1998) suggested that administrators of campus recreational programs are given the highest responsibility of diversifying their skills and knowledge to meet the needs of the entire university and college campus. Campus recreation administrators have a responsibility to be prepared in order to effectively lead, manage, supervise, and direct their programs and services to a diverse population. Campus recreation administrators are responsible for involving students in educational purposeful activities.

Campus recreation administrators see their work related responsibilities and obligations as vital to their ability to create environments that serve the recreational and learning needs of others. A description of a range of campus recreation administrator's job duties and responsibilities can be seen in Table 1. The items described here should help identify a campus recreation administrators worth to a university and college campus.

\section{Challenges for Campus Recreation Administrators}

The responsibilities and obligations shown in Table 1 significantly impact the effectiveness of campus recreation programs. It is the job of a campus recreation administrator to assess, plan, implement, and evaluate their programs effectively (Byl, 2002). To do this, campus recreation administrators are being required to have a 
Table 1

Summary of Campus Recreation Administrator's Job Duties and Responsibilities

Supervision:

1. Directly supervise full-time staff, graduate assistants and administrative assistants.

2. Responsible for the operations of facilities (i.e. Recreation Center) and oversees all program areas.

3. Provides evaluation and feedback for full-time staff and student staff.

Staff Selection and Development:

1. Coordinate the recruitment and selection of full-time staff, graduate assistants and student employees.

2. Develop and administer training for the program and operation staff.

3. Develop a departmental strategic plan.

4. Create, maintain, and update staff manuals and position descriptions.

Administration:

1. Oversee programs offered within campus recreation
a. Intramurals
b. Sport Clubs
c. Group Fitness and Wellness
d. Aquatics
e. Outdoor Recreation and Pursuits 
Table 1 (continued)

Summary of Campus Recreation Administrator's Job Duties and Responsibilities

\section{f. Special Events}

g. Outdoor facilities (i.e., athletic fields, courts, etc.).

2. Responsible for scheduling, supervision and management of facilities (i.e. Recreation Center).

3. Responsible for budget and financial operations

4. Manage, administer, and enforce membership and participation policies and procedures.

5. Responsible for professional development of all full-time staff.

6. Responsible for marketing and promotion initiatives.

7. Act as department's liaison to various university administrative offices.

8. Works directly with the administration of student affairs Related Responsibilities:

1. Represents campus recreation department at special university activities.

2. Supports recruitment and retention efforts through guidance and leadership.

3. Serves as designated member of institutional committees (when assigned).

competency-based education. According to Barcelona and Ross (2004), campus recreation administrators must be educated and competent in "business, management, communication, technology, legality/risk management, research and evaluation, and event programming" (p. 46). 
Campus recreation administrators have a responsibility to challenge themselves as well as their programs to meet the needs of their participants. The campus recreation profession can differ from campus to campus. Young and Ross (1998) explained that in recent years, campus recreation programs of all types and sizes have had to address challenges in areas such as funding and budgets, legal matters, and technology. "What were once departmental budgets expressed in thousands of dollars have grown into programs with multimillion-dollar budgets and elaborate recreation centers" (Taylor et al., 2003, p. 85).

Other issues have included participant problems, political pressures from campus constituency groups, and a board that advises and supervises staff and subordinates. Consistent with those findings from Barcelona (2004) and Barcelona and Ross (2004) revealed that university type and institutional size do make a difference in the competencies and expectations of a campus recreation administrator. Those studies by Barcelona and Barcelona and Ross showed that campus recreation administrators at smaller institutions with fewer staff are required to have more responsibilities and specific knowledge due to the lack of staff to carry out specified roles. Those studies also indicated that campus recreation administrators who have large staffs spent more of their time on issues related to communication, coordination, and control, and less in the overall management of a campus recreation department (Barcelona, 2004; Gaskins, 1992; Slack, 1997).

Campus recreation administrators more then ever are pressured to increase program productivity and efficiency, plan and budget for program enhancement, increase participation, monitor staff and student employees, manage recreational facilities, and 
manage a limited amount of resources efficiently (Zhang et al., 2004). A great deal of responsibility also lies in the ability to deal with the challenges of providing services and programs to large, diverse, and demanding student populations. Cooper and Faircloth (2006) stated that "the increasing diversity among college student and the escalating expectations of campus patrons, donors, and accreditating bodies have required campus recreation professionals to increase their foci on standards and benchmarks of practice and outcomes of services" (p. 126).

The boundaries and scope of service for campus recreation is expanding. Young and Ross (1998) stated "every campus recreation administrator has the challenge to plan, guide, and lead his or her organization into the future" (p. 24). Weese (1997) and Lewis et al. (1998) explained that since the late 1980s and early 1990s campus recreation has seen an increased growth in new multimillion-dollar recreation facilities on university campuses. Zhang et al. (2004) agreed that building a state of the art, multimillion-dollar facility increases the demand for "campus recreation administrators to have particular knowledge, experience, and skills to run the intramural sports, sport clubs, fitness, outdoor recreation, aquatics, and/or informal recreation” (p. 185). Bleiklie and Powell (2005) stated that due to new facilities and the demand for an appropriate recreation outlet "pressures are mounting in regards to greater productivity and efficiency, demands for more responsiveness and enhanced application" (p. 1).

Despite the challenges and issues that affect the programming and administration of campus recreation programs, campus recreation administrators must work effectively and efficiently and not be overwhelmed by institutional and administrative factors that they cannot control (Schneider et al., 2007; Zhang et al., 2004). Zhang et al. stated that 
"the well-being and work effectiveness of campus recreation administrators are affected by the institutional and personal factors within which they function” (p. 187). In many cases campus recreation administrators desire the need to work more effectively. They need help sifting through the day-to-day obstacles and challenges they face from higher education institutions.

Although research exists that has investigated the impact of campus recreation programs and services on different institutions (Forrester, 2006; Lindsey \& Sessoms, 2006; Osman et al., 2006; Schneider et al., 2007; Weese, 1997; Zhang et al., 2004), one largely neglected variable is the affect certain demographics of campus recreation administrators have on their job satisfaction. Specifically, this study attempts to determine whether contributing factors such as age, gender, institutional size, institutional type, and years of experience in the campus recreation profession can predict a campus recreation administrator's job satisfaction. Moreover, several researchers have suggested that when studying job satisfaction, demographic variables should be taken into consideration (August \& Waltman, 2004; Bauer, 2000; Serini, Toth, \& Wright, 1997; Vander Putten, McLendon, \& Peterson, 1997). A number of demographic variables potentially may predict the job satisfaction of campus recreation administrators. As campus recreation continues to become an important component to institutions, there becomes a need to study those demographic variables associated with job satisfaction of campus recreation administrators.

\section{Job Satisfaction}

Within institutional, industrial, and social psychology research the concept of job satisfaction is a central research theme (Henne \& Locke, 1985) and is viewed as a goal of 
organizations (Locke, 1976). As research continues to investigate the complex and dynamic process of job satisfaction, it is apparent that there is a continued attempt to investigate and define the various definitions of job satisfaction in the literature (Pettit, Goris, \& Vaught, 1997). In 1976, Locke was one of the first to define job satisfaction. $\mathrm{He}$ defined it as "a pleasurable or positive emotional state resulting from the appraisal of one's job or job experiences" (p. 1300). Later work by Locke and Latham (1990) simplified the definition of job satisfaction as the favorableness or unfavorableness with which employees view their work. A short time later, Balzar et al. (1997) defined job satisfaction as feelings that employees have regarding their work environment and their expectations towards work. Thus, job satisfaction can be recognized as what one wants or values from a job (Brief \& Weiss, 2002). These authors, as well as others, suggest that in any job, the way in which an employee views his or her work influences the amount of satisfaction (morale) he or she receives from the job (Heyle, 2007; Spector, 1997).

Identifying what job characteristics make employees satisfied requires the ability to effectively study the environment that alludes to a sense of belonging and a fulfillment of social needs, and is conducive to a quality work life. Kulhavy and Schwartz (1981) and Llorente and Macias (2005) pointed out that the work environment can have a major influence on job satisfaction. According to Gordon, Anderson, and Bruning (1992), institutions have a responsibility to commit themselves to their employees' welfare, rights, and product quality. Carlson and Mellor (2004) stated that "satisfaction is expected when a job allows an incumbent to be engaged in intrinsic forms of selfexpression" (p. 238). Being able to link characteristics of work identity with specific job characteristics serves as important antecedents of job satisfaction. 
The prevailing argument by Morrison (2002) is that organizations must be responsive to not only providing a job and income, but a positive work environment. Pettit et al. (1997) and Eisenberger, Fasolo, and Davis-LaMastro (1990) agreed that when employees are content with their organization, they feel their work and contributions are valuable assets and will to a certain extent influence the amount of satisfaction (morale) they receive from the job. King, Lahiff, and Hatfield (1988) reported that there was a "consistently clear and positive pattern of relationships between an employee's perceptions of their work and his or her job satisfaction" (p. 36). Thus, employees who are able to improve their work experience often experience an enhancement in their overall well-being and are most likely to succeed (K. A. Brown \& Mitchell, 1993; Eisenberg \& Goodall, 2004; Wheatley, 2001; Sias, 2005).

A growing body of research is being done that investigates employees' work and motives and how it explains satisfaction with the job (C. M. Anderson \& Martin, 1995). Zhang et al. (2004) suggested that certain motivational factors contribute to job satisfaction such as "achievement, recognition, work itself, responsibility, advancement, and professional growth" (p. 187). Likewise, Kreitner and Kinicki (2006) summarized that there were positive correlations between job satisfaction and an employees' mental well-being, commitment to the job, and motivational factors. King et al. (1988) reported that there was a "consistently clear and positive pattern of relationships between an employee's perceptions of their job duties and responsibilities and his or her job satisfaction" (p. 36). Studies demonstrate when people's needs are met through a satisfying work environment they are more than likely to remain at their job and experience satisfaction (A. M. Rubin, 1993). Conversely, unfulfilled needs result in 
counterproductive work behaviors and high degrees of dissatisfaction with their job (R. B. Rubin \& Rubin, 1992). A counterproductive work environment contributes to feelings of dissatisfaction with superiors, job duties and responsibilities, and ultimately the institution (Jablin \& Krone, 1994).

Contributions are being made to the study of job satisfaction. Downs, Clampitt, and Pfeiffer (1988) and Pincus (1986) concluded there is clear evidence that positive work relationships, good rapport with administration, and clear job responsibilities increase job satisfaction. Robertson (2003) pointed out that a supportive work environment fosters a sense of satisfaction among employees. Additionally, Brief and Weiss (2002) suggested that there is an association between those workers who experience greater interpersonal satisfaction (relationships with faculty, staff, and students) and higher levels of job satisfaction. Zhang et al. (2004) agreed that job satisfaction is not merely an employee's responsibility but an organization's ability to satisfy the "needs, values, and expectations of employees" (p. 187).

\section{Job Satisfaction in Higher Education}

Higher education administrators are beginning to realize that employees can not be taken for granted. Institutions are dealing with a new breed of employee who is looking for job satisfaction, who believes in personal options and independence, and who wants meaningful work (D’Aprix, 1996). Research suggests that there is clear evidence that a meaningful work environment increases job satisfaction (D'Aprix, 1996; Downs et al., 1988; Pettit et al., 1997; Pincus, 1986; Sias, 2005). Chappell (1995) and Levy (1989) had similar findings that suggested there were various organizational and individual work environment variables such as "internal communication, organizational structure, 
political climate, participation in decision making, independence, benefits, and job effectiveness" that provided increased levels of satisfaction with one's work (Zhang et al., 2004, p. 188).

According to Pettit et al. (1997), a meaningful climate incorporates "high levels of accuracy of information which leads to high levels of performance, and successful performance promotes job satisfaction" (p. 94). Evidence is accumulating that reports that a meaningful work environment leads to satisfaction by providing employees with a sense of ownership of their work and outcomes (Clements-Croome, 2000; Infante, Anderson, Martin, Herington, \& Kim, 1993; Infante \& Gorden, 1991; Vischer, 2007). According to Mueller and Wallace (1996), Tyler and Cushway (1998), and Zhang et al. (2004), the lack of resources, less rewarding work conditions, lack of support from supervisors and co-workers, and heavy workloads have an effect on an employee's satisfaction toward their jobs. Thus, an employee's level of satisfaction may be shaped by multiple features of a particular department and institution.

Higher education institutions need to acknowledge the importance of analyzing the campus recreation work environment and its employees because campus recreation plays a key role in the recruitment and retention of students. For universities to be competitive they must be prepared to offer "expertly conceived, promoted, staged, and evaluated" campus recreation programs (Weese, 1997, p. 265). But to do this, universities must realize that campus recreation is not just a component of student affairs, but an important tool that helps develop the overall makeup of the institution (Cooper \& Faircloth, 2006). 
Further research is needed to assess the impact a campus recreation administrators' work environment has upon his or her satisfaction with the job. If higher education administrators are to assume responsibility for managing the campus recreation work environment, they need a way of regularly measuring their employee's satisfaction. If campus recreation administrators are to manage their personal work environment and job satisfaction, they need a way in which it may be measured. To develop a more specific, comprehensive picture of the variables that can affect an employees' job satisfaction, studies must be able to determine the relationships between numerous job satisfaction variables.

\section{Job Satisfaction Variables}

Identifying the relationship between a campus recreation work environment and other institutional variables is important. Research on work environments focuses upon many variables which have a direct influence on the institutional life of an employee (Spector, 1997). Variables exist that penetrate the offices, meeting rooms, and operational facilities. Higher education institutions must be able to identify those variables which should be addressed in any program to improve the work environment (Spector). Pettit et al. (1997) explained that the systematic way of studying campus recreation administrator's job satisfaction is to identify facets that exert their influence and identify an employee's satisfaction with a job. By focusing on campus recreation attributes, it provides a clear idea of what variables have an affect on job satisfaction.

Because an employee's level of satisfaction varies with specific aspects of the job, it is proposed that numerous facets (variables) from the Job Satisfaction Survey (JSS) underlie this construct. The JSS (Spector, 1997) assesses nine facets of job satisfaction. 
These elements have been classified by Spector into nine distinct dimensions: Pay, Promotion, Supervision, Fringe Benefits, Contingent Rewards (performance based rewards), Operating Procedures (required rules and procedures), Coworkers, Nature of Work, and Communication. It is the intent of this section to provide a theoretical understanding of the variables involved when studying job satisfaction. This approach can be useful when a complete picture of employee job satisfaction is warranted. Pay

Pay is defined as a method of compensation for doing routine, scheduled, or interval tasks as prescribed by a job. According to Spector (1997), pay level is not as important when compared to pay fairness. Terpstra and Honoree (2004) reported that most employees are not concerned with pay towards people in different jobs, but rather when people earn more in the same job. Spector (1997) suggested that consistency and justice of pay policies is more of an influence than a difference in salary. Terpstra and Honoree found that organizations should be concerned with both external and internal equity of pay policies. They concluded that when a university's pay scale is externally competitive employees showed a higher level of satisfaction with their job and pay.

\section{Promotion}

According to Kramer and Nolan (1999) promotion refers to the furthering of or the advancement of one's job. Promotion offers the opportunity to transition beyond current job tasks and responsibilities and provides an avenue to broaden one's skills and talents. Cassel and Kolstad (1998) and Varhol (2000) agreed that promotion could be the next logical step in a successful career and a way to regain a passion for work. 


\section{Supervision}

Supervision relates to the autonomy an employee receives from his or her immediate supervisor to make decisions about his or her job. Spector (1997) explained that supervision can provide employees the opportunity to have input into policy issues and autonomy over their job tasks. Spector (1985) conducted a meta-analysis that showed the amount of autonomy given to employees had an effect on an employees' job satisfaction. Supervision is a broad term that also refers to management style and compatibility with employees. Previous research (Beehr et al., 2006; Holloway, 1995) showed that employees who were able to develop effective interpersonal relationships with their supervisor reported being more satisfied with their supervisor and work conditions.

Fringe Benefits

Fringe benefits are a form of compensation that is provided in addition to salary such as health insurance, retirement pay, and life insurance. Employee compensation packages are seen as important factors when determining an employee's satisfaction with the job (Tremblay, Sire, \& Balkin, 2000). Benefits have the ability to attract and retain employees. How important are fringe benefits? According to Hart and Carraher (1995) "benefits inequity could result in the converse, namely, dissatisfaction, higher levels of absenteeism, lower levels of performance, and higher turnover rates" (p. 481).

Furthermore, Kouzes and Posner (1995), Milton (1989), and Weathington and Tetrick (2000) suggested that an organization's benefit package and the motive of the organization to provide appropriate benefits both have a direct relationship with employee attitudes and job satisfaction. 


\section{Contingent Rewards}

Contingent rewards refer to those non-wage forms of compensation that recognize, appreciate, and reward employees for good work. According to Viken and McFall (1994), contingent rewards are expected to increase or "reinforce" certain desired behaviors (p. 122). Aplander and Lee (1995) stated that "institutions must examine the extent to which its reward and recognition system motivates individuals, team, and institutional performance improvement" (p. 5). When administration offers incentives and rewards to employees it has an effect on effort and performance (Klein \& Higgins, 1992). Therefore, expectancy of rewards and other value-added incentives are primary determinants of an employee's motivation.

\section{Operating Procedures}

Organizations are made up of operating procedures that explain the work

processes that are to be performed and followed by employees of that organization. In most organizations employees are charged to identify ways to adhere to an organization's operating procedures while managing their workload (Aplander \& Lee, 1995). Operating procedures exist to facilitate a working environment that employees can understand and follow (Andorka, 2003). Furthermore, ineffective operating procedures can help explain why employees are dissatisfied with work related policies, goals, and responsibilities within the organization (Rosenfeld, Richman, \& May, 2004).

\section{Coworkers}

Several studies take a social approach to job satisfaction, examining the influence of coworkers on job satisfaction. According to Hodson (1997), an employee's level of job satisfaction might be a function of personal characteristics and the characteristics of the 
groups to which the employee belongs. DeVaney and Chen (2003) and Ducharme and Martin (2000) suggested that the social context of work is likely to have a significant impact on a worker's attitude and behavior. Relationships with both coworkers and supervisors are important. A study by Kalleberg and Mastekaasa (2001) has shown that the better the relationship, the greater the level of job satisfaction and quality of the work relations with colleagues and administration.

\section{Nature of Work}

Job tasks that characterize the work place also are likely to play a definite role in job satisfaction among workers. According to Spector (1997), such job tasks can make the job meaningful, can create a sense of pride in doing the job, and can make the job enjoyable. Basom and Frase (2004) and Staudt (1997) found that job satisfaction was greater among workers in jobs that had allowed them to exert their own judgment to get work done and demonstrate their ability to delegate tasks. Previous studies by Blau (1999) and DeVaney and Chen (2003) have shown that job satisfaction is negatively related to the performance of routine tasks, yet positively related to the performance of more complex and autonomous tasks.

\section{Communication}

“Members of today's complex institutional structures must face increasingly difficult challenges to address the role of communication" (Rosenfeld et al., 2004, p. 29). Baker (1992) stated that without "strong and weak task-related communication, informal socializing, advice-giving, and advice getting organization may suffer from work-related disintegration" (p. 400). Attempts have been made to investigate institutional communication and explain the motivation of an employee's communication habits with 
coworkers and bosses (C. M. Anderson \& Martin, 1995). Studying communication issues in interpersonal relationships at work are popular research focuses. One reason is that employees need communication with superiors and coworkers to understand their environments and roles (Jablin \& Krone, 1994). In fact, superior/ subordinate communication is one of the most frequently researched topics (Allen, Gotcher, \& Seibert, 1993; Jablin \& Krone, 1994). Studies demonstrate when people's needs are met through satisfying communication, they more than likely build relationships, stay in them, and experience satisfaction (A. M. Rubin, 1993). Conversely, counterproductive communication contributes to feelings of dissatisfaction with superiors, jobs, and organizations (Jablin \& Krone, 1994).

\section{Conclusion}

A thorough examination of the phenomenon of job satisfaction of campus recreation administrators was drawn from literature on higher education, campus recreation theories, and the emerging effect on job satisfaction. Theoretical and empirical studies for each category were discussed.

In order to study job satisfaction of campus recreation administrators, attention was given to the related literature on such areas as (a) higher education administration, (b) impact of student affairs, (c) growth of campus recreation, (d) challenges affecting campus recreation administrators, (e) job satisfaction, and (f) job satisfaction variables. The literature suggested that understanding a campus recreation administrator's work environment enables a thorough connection with his or her satisfaction on the job. The significance of an investigation of job satisfaction of campus recreation administrators is 
evident from the lack of research relating to both topic areas. The degree to which these two categories affect each other is discussed in Chapters 4 and 5.

The apparent implications these topics have on the construct of higher education merits further investigation. There is a need to learn more about the role universities and colleges play in the overall job satisfaction of campus recreation administrators. It is critical that continued progress is made towards the examination of the relationship that exists between job satisfaction and the job tasks of campus recreation administrators. Because there is such a limited amount of research on this topic, studying job satisfaction of campus recreation administrators at 4-year public and private institutions is justified. To address these issues, a study which analyzes job satisfaction of campus recreation administrators at 4-year universities and colleges is warranted. 


\section{CHAPTER III RESEARCH METHODOLOGY}

This chapter describes the research methodology used in this study. This chapter includes nine sections: (a) purpose of study, (b) variables, (c) research questions, (d) selection of the sample, (e) instrumentation, (f) reliability, (g) validity, (h) distribution procedures, and (i) data analysis procedures.

\section{Purpose of the Study}

The literature review indicated that in recent years, campus recreation has been seen as an integral part of a college campus. However there continues to be a limited number of studies that look at job satisfaction of campus recreation professionals. A current analysis of campus recreation administrators at 4-year institutions will identify how significantly different aspects of the job contribute to satisfaction with the job.

The purpose of this study was to determine to what degree campus recreation administrators at 4-year institutions expressed their job satisfaction. Using the Job Satisfaction Survey (JSS), this study used the nine sub facets of job satisfaction and examined which subscale was more satisfying than others. This study also examined whether gender, age, institutional size, and years of experience explained various levels of job satisfaction. 


\section{Variables}

The conceptual framework used in this study was created based upon the theoretical understanding of the work environment of campus recreation and the various factors related to job satisfaction. The dependent variables in this study were the measure of overall job satisfaction and the nine sub facets of job satisfaction. These nine sub facets included pay, promotional opportunities, fringe benefits, contingent rewards, supervision, co-workers, nature of work, communication, and work conditions. A description of all nine factors measured is provided in Table 2 (Spector, 1997). The independent variables of gender, age, institutional size, and years of experience were used. The strength of these relationships among the independent and dependent variables was examined by testing the hypotheses of this study.

\section{Research Questions}

This study was designed to understand the degree to which campus recreation administrators at 4-year institutions were satisfied with their job. The research questions were:

1. To what degree do campus recreation administrators at 4-year institutions express their job satisfaction?

2. Do gender, age, institutional size, type of institution, and years of experience explain the overall level of job satisfaction?

This study used the independent variables from Research Question 2 to test the following null hypothesis:

1. Gender, age, institutional size, and years of experience do not predict the overall job satisfaction score. 
Table 2

Summary of Facets Used in the Job Satisfaction Survey (JSS)

Organizational Variables Description

Pay Pay and remuneration

Promotion Promotion opportunities

Supervision Immediate supervisor

Fringe Benefits Monetary and non-monetary fringe benefits

Contingent Rewards Appreciation, recognition, and rewards for good work

Operating Procedures $\quad$ Operating policies and procedures

Coworkers People you work with

Nature of Work Job tasks themselves

Communication Communication within the organization

\section{Selection of Participants}

All mid-level campus recreation administrators from 4-year institutions in the United States were the target population for this study if they were involved in the programming of any on or off campus recreation program, activity, or event. According to Zhang et al. (2004), campus recreation administrators were defined as mid-level administrators who were classified between "the top administrators and the first levels of supervisors responsible for administering campus recreation programs and supervising professional and student staff members" (p. 190). Programs or events considered were aquatics, extramural events, fitness, health/wellness, intramurals, outdoor pursuits, 
special events, and sport clubs. For selection purposes, campus recreation administrators were considered if their title was director, associate director, assistant director, facility manager, and director of intramurals. Individuals who were not listed with those titles were eliminated from the list.

In order to understand the degree to which campus recreation administrators at 4year institutions were satisfied with their job, a quantitative survey research study design was used. The advantages to using survey research include the possibility of collecting data from a large sample size and being able to gather data on real situations (Davis, 2005; Fraenkel \& Wallen, 2003). Given the large sample size and lack of research funds for the survey distribution, a research design of systematic sampling is used for this study. According to Ary, Jacobs, and Razavieh (2002), systematic sampling is a sampling method that can be used when you want to give the target population an equal chance of being chosen. The major advantage to systematic sampling is that the research can be assured that the measure accurately represents and produces a high degree of generalizability for campus recreation administrators who work at 4-year colleges and universities.

To address the question of how many survey participants are needed for this study, it is important to do a statistical power analysis. Cohen (1992) explained that the statistical power of a test is the long-term probability associated with the type II error, given the effect size, the risk of type I error, and sample size of rejecting the hypothesis. Cohen defined effect sizes as small, medium, and large and developed these effect size norms in order to make it easier to estimate statistical power. 
For this study a type I error of .05 was used which took into account a medium effect size. Taken the conventional type I error of .05, power of .80 (20\% of type 2 error), for a sample size of 773 , Cohen's work indicates that an effect size of .40 or 78 returned surveys are required to reject the null hypothesis. Therefore, the desired response rate of $40 \%$ or 78 returned surveys was appropriate using Cohen's table for statistical power.

The challenge of this study was to minimize both type I and type II errors. To reduce a type I error it was considered important that the hypothesis test procedure used was adjusted so that there was a 'low' probability of rejecting a true null hypothesis. For this study the type I error level was computed as $p \leq 0.05$. This type I error level allowed the researcher to control the amount of risk taken within this study by falsely rejecting a true null hypothesis.

A type II error refers to the chance that the tests will miss the effect. In other words, it declares that there is no significant difference when in fact there really is. A type II error is frequently due to sample size being too small and not reflective of the population. However, because the sample for this study was less variable (a homogeneous population), a smaller sample size was being used. To reduce type II error, and to increase the power of this study, the researcher used Cohen's table, which showed the needed effect size. By matching the required effect size ( $40 \%$ or 78 returned surveys) with that of the sample size, the likelihood to keep type II error within acceptable range was reasonable. Therefore using Cohen's statistical power analysis for this study supported the use of desired sample size mentioned above.

The National Intramural Recreational Sports Association (NIRSA) is the most recognized organization that supports the growth of campus recreation. The accessible 
population of this study was 773 public and private 4-year colleges and universities listed in the National Intramural Recreational Sports Association's Recreational Sports Directory (NIRSA, 2007). The 773 institutions included in the inventory were representative of all geographic regions in the United States.

By using systematic sampling, a random number of 4 was selected which allowed for the $4^{\text {th }}$ member on the list and every $4^{\text {th }}$ thereafter be selected from the NIRSA Recreational Sports Directory (Gall, Gall, \& Borg, 2003). By selecting the random number of 4 , it allowed the researcher to sample one-fourth of the entire accessible population and to select from the population at a regular interval. Invited to participate in this study were 192 campus recreation administrators. The goal of this study was to achieve at least a $40 \%$ response rate. If the desired response rate of $40 \%$ had not been met after the first sampling, a second systematic sampling of the accessible population would be conducted.

\section{Instrumentation}

A survey instrument, described in detail below, was used for the purpose of collecting data from campus recreation professionals relating to the research questions and null hypothesis. The Job Satisfaction Survey (JSS) developed by Spector (1985) was used to collect data (Appendix A). The JSS was designed specially to be used in human service, public, and nonprofit organizations in order to measure evaluative factors of job satisfaction. Based on a review of the job satisfaction literature and a conceptual analysis of satisfaction facets, Spector established nine facets of job satisfaction. These facets included satisfaction with pay, promotional opportunities, fringe benefits, contingent rewards, supervision, co-workers, nature of work, communication, and work conditions. 
Spector felt that these nine facets adequately summarized one's measure of overall satisfaction. Spector believed that existing tests were not directly applicable to the human service field and existing scales did not cover all the areas of job satisfaction (Spector). Although the JSS was originally developed for the human service organizations, it can be used with all types of organizations.

The JSS consists of 36 statements which measure job satisfaction using a 6-point Likert-type scale. The survey takes approximately 20 minutes to complete. Each item on the survey assesses employee attitudes about the job and aspects of the job. The JSS uses a summated rating scale that is formatted with six agree-disagree response choices: disagree very much, disagree moderately, disagree slightly, agree slightly, agree moderately, and agree very much. Approximately half of the 36 questions were written in a positively worded direction and the other half in a negatively worded direction. Questions that were worded negatively were given a reverse score. A score of 6 represents the strongest agreement with a negatively worded item. A score of 6 is therefore considered equivalent to a score of 1 which represents the strongest disagreement on a positively worded item. This method allows sum scores to be combined meaningfully (Spector, 1997).

The JSS is based on nine subscales. Each subscale is represented by 4 questions with each question scored from 1 to 6 . Each subscale score can range from a minimum score of 4 to a maximum of 24 . Based on a sum of all 36 questions, scores can range from a minimum of 36 to 216 . Table 3 indicates which questions correlate to the respective subscale/dimension of job satisfaction (Spector, 1997). 
Table 3

Job Satisfaction Survey (JSS) Scoring Guide and Internal Consistency Reliability

\begin{tabular}{lcc}
\hline Subscale & Item numbers & Alpha \\
\hline Pay & $1,10,19,28$ & 0.75 \\
Promotion & $2,11,20,33$ & 0.73 \\
Supervision & $3,12,21,30$ & 0.82 \\
Fringe Benefits & $4,13,22,29$ & 0.73 \\
Contingent rewards & $5,14,23,32$ & 0.76 \\
Operating conditions & $6,15,24,31$ & 0.62 \\
Coworkers & $7,16,25,34$ & 0.60 \\
Nature of work & $8,17,27,35$ & 0.78 \\
Communication & $9,18,26,36$ & 0.71 \\
Total satisfaction & $1-36$ & 0.91 \\
\hline
\end{tabular}

Note. Negatively worded items are 2, 4, 6, 8, 10, 12, 14, 16, 18, 19, 21, 23, 24, 26, 29, 31, $32,34,36$.

\section{Reliability}

The JSS was originally developed, normed, and validated with the human services in mind (Spector, 1985). The norms provided in Table 3 show that the JSS has been used in a wide range of organizations, ranging from public and private sectors (Spector, 1997). Internal consistency reliability (coefficient alpha) was used for each subscale of the JSS 
on a sample of 2,870 . The JSS results for each subscale were above the .50 minimum suggested by Nunnally (1967).

\section{Validity}

In 1985, Spector conducted a research study that provided evidence to support the job satisfaction subscales of the JSS when compared to different scales on the same employees. The Job Descriptive Index (JDI), which is one of the most validated scales of job satisfaction, was used for comparison of subscales with the JSS and findings indicated that the subscales correlated well with each other; particularly on the five subscales of pay, promotion, supervision, coworkers, and nature of work (Spector, 1997). These correlations between the equivalent subscales showed values of .61 to .80 (Spector 1985, 1997). In addition to the JDI, the JSS has also been shown to correlate well with other instruments with similar subscales.

Since the development of the JSS in 1985, which was developed for use within the human service profession, it has been used in over 115 studies with a total sample size of over 30,000. According to Spector (1997), one of the easiest and convenient ways to assess job satisfaction within an organization is to use an existing scale. Table 4 indicates the JSS norms reflective of all the American samples since the survey's development (Spector, 1997).

A method used to test the instrument for face and content validity was conducted on February 21, 2007. This method used two steps to check the validity of the Job Satisfaction Survey. First, panels of experts were asked to review the instrument for face and content validity. A panel of three experts (Appendix B) reviewed the instrument for face and content validity during February 12-16, 2007. The panel was asked to complete 
Table 4

Job Satisfaction Norms: Total Americans

Facet

Mean

Standard Deviation of Means

Pay

3.03

0.60

Promotion

4.00

0.45

Supervision

4.68

0.45

Fringe Benefits

3.60

0.55

Contingent Rewards

0.48

Operating Conditions

0.50

Coworkers

4.48

0.38

Nature of Work

4.73

0.45

Communication

0.50

Total Satisfaction

3.78

0.32

Note. Number of Samples $=116$, Total Sample Size = 30,382, June 22, 2006

a comment form (Appendix C) and identify any survey questions and content that did not relate to the campus recreation profession.

The second step to check the validity of the JSS was conducted on February 21, 2007. Ten student campus recreation employees were asked to complete a comment form (Appendix D) and identify any questions and content that did not relate to the campus recreation profession. After the three panel experts and the 10 student campus recreation employees completed the field test, the researcher examined the instrument. All comment 
forms submitted by the three panel experts and the 10 student employees reported no adjustments or changes to the survey questions and content. Therefore no changes were made to the instrument used for this study.

\section{Data Collection Procedures}

The Job Satisfaction Survey was administered to campus recreation administrators who work at 4-year colleges and universities in the U.S. Prior to administering the survey, permission was granted from the institutional review board for research with human subjects of The University of Akron (Appendix E). A mail survey packet was sent to 192 participants (one survey per institution). Each packet included a cover letter (Appendix F), the Job Satisfaction Survey, and a self-addressed and prestamped return envelope. Participants were given four weeks to respond. Approximately two weeks from the first mailing of the instrument email follow-up reminders (Appendix G) were sent to those participants that did not complete the mailed survey.

For the email follow-up method, the JSS was entered into survey monkey and a link to the JSS (web-based survey) was attached to the post-card. Participants were given two weeks to respond. Approximately one week from the first email, another email reminder was sent to the participants that did not complete the mailed survey or webbased survey. After three weeks, completed surveys were obtained from survey monkey.

Although anonymity could not be achieved, the researcher kept all information confidential. Participants' names and institution names were used, and all survey results were reported in summary form only. All information provided was kept confidential. To ensure confidentiality, once the surveys were completed and returned, a coding system was used and any identifiable information was removed. Data collected for this study 
were kept in a locked cabinet in the lead investigator's place of business (Ashland University). Data will be kept for one year after completion of study and will be disposed by shredding data and related materials.

\section{Data Analysis Procedures}

Data collected from the JSS was entered and analyzed using procedures from the SPSS for Windows 15.0. A mean score was calculated for the nine job facets and the overall level of job satisfaction measured by the JSS. Descriptive statistics were used to report all data collected. Regression analysis was conducted to examine whether the proposed null hypothesis was supported or rejected. After data were entered from all returned surveys, the research randomly selected $20 \%$ of the returned surveys to check for accuracy of data input. 


\section{CHAPTER IV}

\section{RESULTS}

This chapter presents the results of the statistical analysis and a description of the respondents (campus recreation administrators). The review of results is guided by the two research questions. This chapter includes a presentation of five sections for analyzing the data collected for the study. The five sections are: (a) preliminary analysis, (b) sample description, (c) scale properties - reliability, (d) descriptive statistical analysis, and (e) summary. The data were analyzed using Statistical Package for Social Sciences (SPSS 15.0 for Windows), using the procedures described in the previous chapter.

\section{Preliminary Analysis}

The JSS survey included two parts (see Appendix A). Part I of the survey elicited the demographics of the participants involved in the survey. Part II of the survey consisted of 36 statements measuring job satisfaction using a 6-point Likert-type scale. Each item on the survey assessed employee attitudes about the job and aspects of the job.

Once the surveys were completed and returned, the researcher coded the surveys. The process of data coding involved assigning a numerical value to each of the items addressed on the survey. The JSS uses a summated rating scale that is formatted with six agree-disagree response choices: disagree very much, disagree moderately, disagree slightly, agree slightly, agree moderately, and agree very much. Each response choice question was scored from 1 disagree very much to 6 agree very much. Approximately 
half of the 36 questions were written in a positively worded direction and the other half in a negatively worded direction. Questions worded negatively were given a reverse score. After each survey item was coded accordingly a SPSS data sheet was created that organized and assembled the raw data for statistical analysis. The method used to account for missing data was to substitute the middle response for each of the missing items (Spector, 1985). Because the center of the JSS scale is between 3 and 4, either number was used. Scores of 3 and 4 were alternated as missing items occurred.

\section{Sample Description}

The accessible population of this study was 773 mid-level campus recreation administrators listed in the National Intramural Recreational Sports Association's Recreational Sports Directory (NIRSA, 2007). A systematic sampling of 192 mid-level campus recreation administrators received a mailed survey packet and a web-based survey of the JSS. A total of 104 surveys ( 86 by mail and 18 by web) were returned resulting in a 54\% response rate of useable data for purposes of data analysis. An additional seven surveys ( 2 by mail and 5 by web) were returned on which respondents did not finish the survey; these surveys were deemed unusable for the purpose of this study and were discarded.

\section{Demographic Analyses}

Demographics of the respondents revealed that $75 \%$ identified themselves as male, and $25 \%$ as female. As to the age of the subjects, $3.8 \%$ were under $25,40.4 \%$ were $26-35,20.2 \%$ were $36-45,32.7 \%$ were $46-55$, and $2.9 \%$ were 60 or older.

Participation by type of institution was $61.5 \%$ public and $38.5 \%$ private. As to the student population of the institution, 35 (33.7\%) had less then 5,000 students; 38 (36.5\%) 
were between 5,001 and 15,000; $14(13.5 \%)$ between 15,001 and 25,000; $13(12.5 \%)$ between 25,001 and 40,000; and 4 (3.8\%) had over 40,000. Regarding years in position, the largest group (49 [47.1\%] of the 104 subjects) reported they had been working for the organization for more than 6 years, 20 (19.2\%) subjects between 4 and 5 years, 19 (18.3\%) subjects between 2 and 3 years, and the rest, $16(15.4 \%)$, had worked for the organization less than one year. Description of the participant demographic composition is presented in Table 5 .

\section{Scale Properties - Reliability}

Cronbach's alphas were calculated to examine the reliability of each subscale of the study. The nine subscales in this study were satisfaction with pay (4 items), promotional opportunities (4 items), supervision (4 items), fringe benefits (4 items), contingent rewards ( 4 items), operating conditions (4 items), co-workers (4 items), nature of work (4 items), and communication (4 items).

According to Fraenkel and Wallen (2003), the coefficient alpha should be above 0.70 to determine whether the nine subscales of job satisfaction are reliable. Each of the nine subscales of the instrument met this established criteria for reliability. Reliability tests showed that the internal consistency of the nine subscales was very good for this study. For comparative purposes, reliability results from this study and the JSS norms reflective of all the American samples since the survey's development are reported in Table 6. Each of the nine subscales of the instrument met this established criteria and were comparable to Spector's (1997) norms. 
Table 5

Demographic Characteristics of Campus Recreation Administrators $(N=104)$

Characteristics

Campus Recreation Administrators

$\underline{\mathrm{n}}$

$\underline{\%}$

Gender

Male

78

75

Female

26

25

Age Classification

$\begin{array}{lcc}18-25 & 4 & 3.8 \\ 26-35 & 42 & 40.4 \\ 36-45 & 21 & 20.2 \\ 46-55 & 34 & 32.7 \\ 60+ & 3 & 2.9\end{array}$

Years in Position

Less than 1 year

16

15.4

$2-3$ years

19

18.3

$4-5$ years

20

19.2

More than 6 years

49

47.1

Type of Institution

Public

64

61.5

Private

40

38.5 
Table 5 (continued)

Demographic Characteristics of Campus Recreation Administrators $(N=104)$

Characteristics

Campus Recreation Administrators

$\underline{\mathrm{n}} \underline{\%}$

Student Population

$0-5,000$

35

33.7

$5,001-15,000$

38

36.5

$15,001-25,000$

14

13.5

$25,001-40,000$

13

12.5

$40,001+$

4

3.8

Descriptive Statistical Analysis of JSS Scale

Job Satisfaction Level

Descriptive statistical analysis was conducted to answer Research Questions 1: To what degree do campus recreation administrators at 4-year institutions express their job satisfaction? Respondents were asked questions relating to the nine sub facets of the Job Satisfaction Survey. These nine sub facets included pay, promotional opportunities, fringe benefits, contingent rewards, supervision, co-workers, nature of work, communication, and work conditions. The JSS used a summated rating scale that is formatted with six agree-disagree response choices ranging from 1 to disagree very much to 6 agree very much. 
Table 6

Cronbach's Alpha Coefficients for Campus Recreation Administrators and Spector's Respondents

Job Dimensions

Campus Recreation

Spector's Respondents

\begin{tabular}{lcc}
\hline Pay & 0.80 & 0.75 \\
Promotion & 0.79 & 0.73 \\
Supervision & 0.85 & 0.82 \\
Fringe Benefits & 0.84 & 0.73 \\
Contingent rewards & 0.83 & 0.76 \\
Operating conditions & 0.65 & 0.62 \\
Coworkers & 0.70 & 0.60 \\
Nature of work & 0.70 & 0.78 \\
Communication & 0.75 & 0.71 \\
Total Satisfaction & 0.92 & 0.91 \\
\hline
\end{tabular}

Table 7 illustrates that participants were satisfied with their job when the mean scores were above the mid-point (3.5) of the scale and dissatisfied when below. The highest mean score recorded was for the nature of work subscale $(M=5.32)$ whereas the lowest mean score of 3.14 was for promotion. A mean score of 4.27 was recorded for the total satisfaction. The results indicated that participants are satisfied (above 3.5) with pay, 
Table 7

Descriptive Statistics for Campus Recreation Administrators $(N=104)$ and Spector's

Norms $(N=30,382)$

Job Dimensions

Campus Recreation Mean

Spector's Norms Mean

Pay

3.58

3.03

Promotion

3.14

4.00

Supervision

5.11

4.68

Fringe Benefits

4.30

3.60

Contingent rewards

4.05

3.43

Operating conditions

4.47

3.40

Coworkers

4.95

4.48

Nature of work

5.32

4.73

Communication

4.38

3.63

Total Satisfaction

4.27

3.78

fringe benefits, contingent rewards, supervision, co-workers, nature of work, communication, and work conditions. Promotion was the only sub facet in which campus recreation administrators' scored below the scale's mean. The research calculated the mean and standard deviation of the nine sub facets. The mean scores of the campus recreation sample and Spector's Norms are illustrated in Table 7. Appendix I illustrates the mean of each job satisfaction item along with the nine subscale means. 


\section{Contribution of Demographic Factors}

A linear regression was conducted to answer Research Question 2: Does gender, age, institutional size, type of institution, and years of experience explain the overall level of job satisfaction? The second part of the Job Satisfaction Survey requested demographic information that served as independent variables. Demographic items on the instrument included gender, age, population size of the institution, type of institution (public or private), and years of experience working as a campus recreation administrator.

In order to determine the nature and strength of correlations among the demographic variables, Spearman Correlation Coefficient was used. The null hypothesis tested was:

2. Gender, age, institutional size, type of institution, and years of experience do not predict job satisfaction.

If two of the variables are highly related, a coefficient somewhat close to +1.00 or -1.00 will be obtained. According to Fraenkel and Wallen (2003) the closer the score is to plus or minus one, the greater the relationship. Table 8 presents the magnitude of relationship when interpreting the correlation coefficients ( $r$; Fraenkel \& Wallen, 2003).

Linear regression was utilized for this analysis and resulted in a one variable model. All independent variables were entered into the regression model using the enter method. The enter method was used to simultaneously specify the set of variables and to determine the percent of variance in the dependent variable as explained by the independent variables, to rank the relative importance of the independents and to assess interaction effects (Green \& Salkind, 2008). 
Table 8

Interpreting the Correlation Coefficients (Magnitude of Relationship)

Value of $r$

Description

$.61-.80$

Very high practical importance

$.41-.60$

Practical and theoretical use

$.00-.40$

Little practical importance

Spearman correlations were calculated for each pair of independent variables.

Table 9 presents correlation coefficients for each of the independent variables. The test results indicated that age and years in position $(r=.631)$ and student population and type of institution $(r=.500)$ were variables that showed a statistically significant correlation. All other variables did not have a significant effect on each other.

When variables are highly correlated, they should be examined to identify whether the correlated variables suggest the same information. As a result, one of them may not contribute significantly to the model after the other one is included. Table 9 presents the values of the Spearman correlations among the variables.

Multicollinearity becomes a problem when trying to understand how each of the independent variables impacts each other (Johnson \& Wichern, 2001). Multicollinearity also can cause the confidence intervals on the regression coefficients to be very wide, which threatens the validity of the regression equation. To diagnose multicollinearity 
Table 9

Spearman Correlation Coefficients of Independent Variables

\begin{tabular}{lccccc}
\hline & $\begin{array}{c}\text { Years in } \\
\text { Position }\end{array}$ & $\begin{array}{c}\text { Type of } \\
\text { Institution }\end{array}$ & $\begin{array}{c}\text { Student } \\
\text { Population }\end{array}$ & Age & Gender \\
Years in Position & 1.00 & & & \\
Type of Institution & 0.135 & 1.00 & & \\
Student Population & 0.097 & $-0.500(* *)$ & 1.00 & \\
Age & & & & \\
& $0.631(* *)$ & 0.122 & -0.028 & 1.00 & \\
Gender & & & & -0.038 & \\
\hline
\end{tabular}

** Correlation is significant at the 0.01 level (2-tailed). $(N=104)$

between independent variables, the multicollinearity diagnostics statistics produced by linear regression analysis was used (Vannata, 2005).

Table 10 shows the Tolerance and Variance Inflation Factor (VIF) for the regression model. According to the correlation matrix on Table 9, the four independent variables were substantially correlated with each other. Thus, multicollinearity should be examined for this study. According to Johnson and Wichern (2001) and Mertler and Vannata (2005), values of VIF exceeding 10 are often regarded as indicating multicollinearity, and in weaker models with values above 2.5 may be cause for concern. All VIF values in this study were lower than 2.0, thus although some independent 
Table 10

The Coefficients for the Regression Model

\begin{tabular}{|c|c|c|c|c|c|c|c|c|}
\hline \multirow[t]{2}{*}{ Model } & & \multicolumn{2}{|c|}{$\begin{array}{c}\text { Unstandardized } \\
\text { Coefficients }\end{array}$} & \multirow{2}{*}{$\begin{array}{l}\text { Standardized } \\
\text { Coefficients } \\
\text { Beta }\end{array}$} & \multirow[b]{2}{*}{$\mathrm{t}$} & \multirow[b]{2}{*}{ Sig. } & \multicolumn{2}{|c|}{ Collinearity } \\
\hline & & $\mathrm{B}$ & $\begin{array}{l}\text { Std. } \\
\text { Error }\end{array}$ & & & & Tolerance & VIF \\
\hline \multirow[t]{6}{*}{1} & (Constant) & 3.986 & 0.391 & & 10.184 & 0.000 & & \\
\hline & $\begin{array}{l}\text { Years in } \\
\text { position }\end{array}$ & -0.076 & 0.068 & -0.139 & -1.115 & 0.268 & 0.610 & 1.640 \\
\hline & $\begin{array}{l}\text { Type of } \\
\text { Position }\end{array}$ & -0.123 & 0.142 & -0.097 & -0.869 & 0.387 & 0.765 & 1.307 \\
\hline & $\begin{array}{l}\text { Student } \\
\text { Population }\end{array}$ & 0.027 & 0.062 & 0.049 & 0.437 & 0.663 & 0.740 & 1.351 \\
\hline & Age & 0.171 & 0.075 & 0.276 & 2.272 & 0.025 & 0.644 & 1.554 \\
\hline & Gender & 0.100 & 0.145 & 0.070 & 0.691 & 0.491 & 0.920 & 1.087 \\
\hline
\end{tabular}

Dependent variable: Overall Mean Score (Job Satisfaction)

variables were significantly correlated, multicollinearity does not appear to be a problem for this study.

In Table 10 the standardized Beta Coefficients gives a measure of the contribution of each independent variable to the model. The beta value is a measure of how strongly each predictor variable influences the criterion variable. The beta value for age $(p=.025)$ indicates that the variable has a significant effect on the criterion variable, overall job satisfaction. 
A summary of the regression coefficients is presented in Table 11 and indicates that age significantly contributed to the model. The model accounts for $2.5 \%$ of variance in job satisfaction. Regression results indicate that the overall model does not significantly predict job satisfaction; $\mathrm{R}^{2}=.069, \mathrm{R}^{2} \mathrm{adj}=.021, \mathrm{~F}=1.45, p<.05$. In other words, all the predictors combined did not account for any significant variation in the dependent variable, overall job satisfaction.

Table 11

Regression Model With Five Predictors

Std.

Model $R \quad R^{2} \quad R^{2}$ adj $\begin{gathered}\text { Error of } \\ \text { Estimate }\end{gathered}$ Change Statistics

\begin{tabular}{|c|c|c|c|c|c|c|c|c|}
\hline & & & & & $\begin{array}{c}\mathrm{R}^{2} \\
\text { Change }\end{array}$ & $\begin{array}{c}\text { F } \\
\text { Change }\end{array}$ & df1 & $\begin{array}{c}\text { Sig. F } \\
\text { Change }\end{array}$ \\
\hline 1 & 0.262 & 0.069 & 0.021 & 0.61448 & 0.069 & 1.446 & 5 & $0.215 \mathrm{a}$ \\
\hline
\end{tabular}

a. Predictors: (Constant), gender, age, population size of the institution, type of institution (public or private), and years of experience.

With respect to the collinearity of the independent variables, the Durbin-Watson score of 2.125 (scale $=0-4)$ indicates that the IVs are robust for analyses, that is, there is only a modest inter-correlation among the variables. This is primarily observed with the age and years of experience pairing, and with the student population and type of 
institution pairing (only to a lesser degree). A summary of the regression coefficients is presented in Table 12.

Table 12

Model Summary to Predict Job Satisfaction

\begin{tabular}{ccccc}
\hline Model & $\mathrm{R}$ & $\mathrm{R}^{2}$ & $\mathrm{R}^{2}$ adj & $\begin{array}{c}\text { Durbin- } \\
\text { Watson }\end{array}$ \\
\hline 0.262 & 0.069 & 0.021 & 2.125 \\
\hline
\end{tabular}

a. Predictors: (Constant), gender, age, population size of the institution, type of institution (public or private), and years of experience.

Summary

This chapter has presented the results of the quantitative analyses performed on the data collected through the Job Satisfaction Survey (JSS). To analyze the results, the quantitative data from the two research questions were reported according to the JSS. The sections dealing with the analysis of the research instrument, the description of the sample, and procedures for conducting the study were addressed. A brief description of the statistical tests used to analyze the data was provided. Important findings of this study are summarized as follows:

Research Question 1: To what degree do campus recreation administrators at 4year institutions express their job satisfaction?

- All mean scores for the nine job satisfaction subscales were above the midpoint (3.5) of the scale. The highest mean score recorded was for the nature of 
work variable $(M=5.32)$ whereas the lowest mean score of 3.14 was for promotion. A mean score of 4.27 was recorded for the total satisfaction. In other words, campus recreation administrators from 4-year public and private institutions are satisfied with their job.

Research Question 2: Does gender, age, institutional size, type of institution, and years of experience explain the overall level of job satisfaction?

- The linear regression conducted with all five predictors accounts for $2 \%$ of variance in total job satisfaction, $\mathrm{R}^{2}=.069, \mathrm{R}^{2} \mathrm{adj}=.021, \mathrm{~F}=1.45, p<.05 . \mathrm{In}$ other words, although age emerged as a significant predictor variable, all the predictors combined did not account for any significant variation in the dependent variable, overall job satisfaction. Additionally the null hypothesis, which did not predict a positive relationship between gender, age, institutional size, type of institution, and years of experience, failed to be rejected. 


\section{CHAPTER V \\ SUMMARY, DISCUSSION, AND RECOMMENDATIONS}

\section{Overview}

This chapter consists of six main sections. The first section provides a summary. The second provides findings about the results of this study. The third provides implications for the study. The fourth provides discussion. The fifth provides recommendations for future research and the final section of this chapter provides a conclusion.

\section{Summary}

The statement of the problem revealed that on today's college campus, campus recreation administrators have a high degree of responsibility to diversify their skills and knowledge base to increase the overall quality of the program and service offerings in order to meet the leisure needs, wants, and values of the student body. Campus recreation administrators have been given this professional responsibility by higher education administrators to facilitate a greater awareness of day-to-day operations of campus recreation programs and services and to inject new energy, creativity, focus, involvement, and skills into their professional experience for the betterment of student learning. Campus recreation administrators are seen as powerful influences on university and college campuses and have an opportunity to foster a positive and enriching campus environment that can be valuable to the college community and student development. 
Campus recreation has emerged as an important recruitment and retention tool (Belch et al., 2001; S. C. Brown, 1998; Hunter \& Murray, 2007; Lindsey \& Simmons, 2006; Osman et al., 2006; Zhang et al., 2004). According to Reynolds (2007), institutional characteristics and facilities have a direct correlation with a student's decision to attend various institutional types. Factors such as new recreation facilities and appropriate recreation outlets can play a key role in the decision process for students (Bryant et al., 1995; Moore \& Marsh, 2007, Zhang et al., 2004). Prior research by Banta et al. (1991) indicated that $30 \%$ of the students at six different universities who took the National Intramural-Recreational Sports Associations' Quality and Importance of Recreational Sports instrument considered that the quantity and quality of campus recreation programs was an important factor in their decision to attend a university or college. Their results showed that because of the campus recreation programs and services offered students were more likely to attend and continue at that institution.

It is important that the study of the campus recreation profession continues so that more information and insight into the profession and its impact on higher education institutions are revealed. Because the satisfaction of those responsible for guiding campus recreation can contribute to its effectiveness, investigating job satisfaction for those administrators is prudent. Few studies explore the job satisfaction of campus recreation administrators at 4-year institutions. Research done by Zhang et al. (2004), to this point, has been the only research that investigated and addressed job satisfaction of campus recreation administrators. Zhang et al.'s study evaluated current job satisfaction of campus recreation administrators from both public and private universities and colleges. Identifying specific work environment dimensions that affect job satisfaction among 
campus recreation administrators appears to not only support Zhang et al.'s research, but also advance their research. Further, the current study attempted to determine whether certain demographics such as age, gender, institutional size, type of institution, and years of experience in the campus recreation profession predict a campus recreation administrator's job satisfaction. As campus recreation continues to become an important component of higher education institutions, there is a need to study those demographic variables associated with job satisfaction of campus recreation administrators. Moreover, several researchers have suggested that when studying job satisfaction, demographic variables should be taken into consideration (August \& Waltman, 2004; Bauer, 2000; Serini et al., 1997; Vander Putten et al., 1997).

\section{Findings}

The results of this study presented a number of findings regarding job satisfaction among campus recreation administrators at 4-year public and private institutions. These findings come directly from the analyses and reveal both statistical and practical significance. Chapter 4 presents the results in detail. The following section outlines the results of the two research questions.

The current study examined the degree to which campus recreation administrators at 4-year institutions express their job satisfaction. The data were collected using a mailed-survey and a web-based survey, both of which were sent to the same systematic sample $(N=192)$ of campus recreation administrators who were employed at 4-year public and private institutions according to the National Intramural Recreational Sports Association's Recreational Sports Directory (NIRSA, 2007). During the data collection 
period, 104 campus recreation administrators participated in the study, yielding a return rate of $54 \%$.

The purpose of this study was to answer two questions: Research Question 1: To what degree do campus recreation administrators at 4-year institutions express their job satisfaction? And Research Question 2: Does gender, age, institutional size, type of institution, and years of experience explain the overall level of job satisfaction?

A descriptive statistical analysis was used to answer Research Question 1. According to the analyses of the scores in Chapter 4 (Table 7) the analysis found that eight of nine mean scores for the nine dependent variables (pay, fringe benefits, contingent rewards, supervision, co-workers, nature of work, communication, and work conditions) were above the mid-point (3.5) of the scale. The highest mean score recorded was for the nature of work variable $(M=5.32)$ whereas the lowest mean score of 3.14 was for promotion. A mean score of 4.27 was recorded for the total satisfaction. It is important to analyze the descriptive statistics because the mean scores provide a starting point for identifying to what degree campus recreation administrators express their job satisfaction.

An examination of the nine dependent variables revealed that supervision and nature of work had the highest mean scores. These scores indicate the respondents tend to value supervision and nature of work when related to job satisfaction. Higher education administrators can capitalize on the presence of these two variables. They can explore administrative leadership methods that can lead to a productive management style and an increased compatibility with campus recreation administrators. They can create a work environment that can make the job meaningful and enjoyable, and create a sense of pride 
in doing the job. With that in mind, higher education administrators can explore options to further increase satisfaction of campus recreation administrators.

Linear regression analysis was used to answer Research Question 2. The standardized beta coefficients model revealed that age was the only independent variable that had an influence on overall job satisfaction. Although age emerged as a predictor, variable regression results revealed that all five predictors accounted for only $2 \%$ of the variation in the dependent variable, job satisfaction. In other words, all the predictors combined did not account for any significant variation in the dependent variable, job satisfaction.

\section{Implications}

Trends emerged that provided insight into the work environment of the campus recreation profession. As revealed through the analysis of Research Question 1, supervision and nature of work represent the highest degree of satisfaction for campus recreation administrators. Based on the current findings, supervision and nature of work may lack statistical significance, but may be associated with practical significance.

Based on the findings, supervision is valued in the campus recreation profession. An essential component of supervision seems to be that campus recreation administrators are satisfied when they are giving direct control over campus recreation programming and operation of such. Based on the findings, campus recreation administrators value the right to have autonomy over their job. This is further supported by Spector (1985) who conducted a meta-analysis that showed the amount of autonomy given to employees had an effect on an employees' job satisfaction. Furthermore, Spector (1997) explained that supervision can provide employees the opportunity to have input into policy issues and 
autonomy over their job tasks. Campus recreation administrators want to be able to control the manner in which their programs and services are implemented and organized. Institutions may need to consider developing methods that allow greater autonomy and encourage campus recreation administrators to continue to apply experimentation and innovation to the profession.

A campus recreation administrator's level of job satisfaction was also related to relationships and the characteristics of the groups to which they belonged. Previous research (Beehr et al., 2006; Holloway, 1995) indicated that employees who were able to develop effective interpersonal relationships with their supervisor reported being more satisfied with their supervisor and work conditions. The social context of work is likely to have a significant impact on a campus recreation administrator's attitude and behavior. Thus, campus recreation administrators' relationships with their supervisors and possibly coworkers were highly valued.

Nature of the work environment was also valued in the campus recreation profession. Findings from the current investigation agree with studies by Basom and Frase (2004) and Staudt (1997) who reported that employees expressed greater value in their work environment when they were permitted to exert their own judgment to get work done and demonstrate their ability to delegate tasks. Additionally, the current study, along with Blau (1999) and DeVaney and Chen (2003), has shown that job satisfaction can be negatively related to the performance of routine tasks, yet positively related to the performance of more complex and autonomous tasks. A good working environment will not only help employees remain satisfied with what they do, but also enhance retention and future recruitment efforts. 
Findings from this study show how campus recreation administrators perceive their work environment in relation to job satisfaction. Evidence confirms that campus recreation administrators tend to value supervision and nature of work when related to job satisfaction. Although results indicate that supervision and nature of work were highly valued, it is important to also show that campus recreation administrators were satisfied overall with their jobs.

As mentioned in Chapter 2, a satisfied campus recreation administrator can contribute largely to the success of a university or college. This indicates that campus recreation administrators who are satisfied in their jobs are more likely to serve students well. The current research (Bryant et al., 1995; Moore \& Marsh, 2007) shows campus recreation administrators play an important role in the recruitment and retention of students. Campus recreation administrators have a responsibility to provide quality programs and services that facilitate student development (Hayek \& Kuh, 2004). Therefore student participation in campus recreation supports the idea that the higher a student's satisfaction was with his or her campus recreation experiences resulted in a higher satisfaction in all aspects of campus life.

Nevertheless it is important for higher education administrators to ensure that campus recreation administrators are satisfied in their jobs so they can work effectively and efficiently. Since campus recreation programs and services can directly affect student's learning and development, studying job satisfaction of campus recreation administrators holds practical significance to universities and colleges. Working towards providing justification on the importance of having satisfied campus recreation 
administrators on campus can result in a better working environment and increase academic achievement, student learning, and retention (Gray, 2002).

Research Question 2 revealed that demographics were not statistically significant and did not explain overall satisfaction. Results of this research indicate that campus recreation administrator demographics do not have a significant influence on overall job satisfaction. Nevertheless, these findings deserve further investigation. Zhang et al. (2004) suggested that a few researchers (Bedeian, Ferris, \& Kacmar, 1992; Katz, 1980; Kirkland, 1989; Parkhouse \& Holmen, 1980; Parks, Russell, Wood, Roberton, \& Shewoki, 1995; Parks \& Parra, 1994) indicated that demographics can have an effect on an administrator's well-being and work effectiveness. Whereas the research on demographics within campus recreation is limited, Zhang et al. (2004) suggested that future studies should examine the relationships between demographics and job satisfaction of mid-level administrators in order to stay abreast of changes in the campus recreation profession.

With the limited research on demographics within the campus recreation profession, more studies on this topic are essential to identify any new trends involving campus recreation administrators. This research supports investigating other demographic variables not used in this study. Studying the work environment of the campus recreation by addressing issues relating to demographics can benefit all members of the profession.

\section{Discussion}

The current study focused on job satisfaction which will enable campus recreation administrators to assume responsibility for evaluating their personal work environment. S. C. Brown (1998) suggested that campus recreation administrators need to hold 
themselves accountable for the skills and knowledge areas that are necessary to lead a productive campus recreation program and support student learning and development. Campus recreation administrators have an obligation to understand their roles and responsibilities to educational goals (S. C. Brown, 1998; Cooper \& Faircloth, 2006; Hall, 2006). Taking responsibility for one's actions can be a key motivator that determines satisfaction and can help campus recreation administrators identify specific job characteristics that foster positive outcomes for themselves, their colleagues, and students.

It is no surprise that increasing productivity, service quality, and employee satisfaction are ideas that would be encouraged and supported by any university and college. Over the years, universities and colleges have had to consistently and effectively apply new ideas and trends that affect the complexity and diversity of its employees and work environment (Eckel \& Kezar, 2003; Kezar, 1999; Morrison, 2002). Generally, that means higher education administrators establishing outcomes that help employees to do their jobs better. These outcomes should be the process by which needs become objectives and the objectives become programs. Rubin (1993) reported that when employee needs are met in the workplace they are more than likely to remain at their job and experience satisfaction.

Given the importance of a positive work environment (C. M. Anderson \& Martin, 1995; Brown \& Mitchell, 1993; Eisenberg \& Goodall, 2004; Wheatley, 2001; Morrison, 2002; Sias, 2005; Zhang et al., 2004), studying job satisfaction of campus recreation administrators can lead the way towards the development of new and existing strategies that can help all university employees be more productive and learn with their jobs. One 
strategy that higher education administrators might employ is professional development. Professional development is a process where creating opportunities, releasing potential, removing obstacles, encouraging growth, and providing guidance is essential (J. L. Anderson, 2005). Zhang et al. (2004) suggested that job satisfaction is not merely an employee's responsibility but an organization's ability to satisfy the "needs, values, and expectations of employees" (p.187). Professional development offers the opportunity to enhance an individual's life, the organization's culture, and community. Employees who are able to improve their work experience often experience an enhancement in their overall well-being and are most likely to succeed in their job (K. A. Brown \& Mitchell, 1993; Eisenberg \& Wheatley, 2001; Goodall, 2004; Sias, 2005). Therefore, research suggests that a meaningful work environment increases job satisfaction (D'Aprix, 1996; Downs et al., 1988; Pettit et al., 1997; Pincus, 1986; Sias, 2005).

Establishing new practices and techniques to current job responsibilities is a challenging process that requires time and extra effort. Guidance, direction, and support are essential when implementing a professional development experience (Wald, 2000). If higher education administrators want to implement a professional development plan, it must be built into the infrastructure of the university or college. In creating long-term plans, higher education administrators need to consider the research on the importance of effectively providing intense professional development, monitoring its implementation, and effectively evaluate the results. A meaningful work environment that incorporates professional development should have fundamental principles, those of which are reflected in the following statement by Elizabeth Foote (1999):

Organizations need to continue to focus there time on socializing new employees, define the changing demands and expectations of positions, find innovative ways 
of doing more with les, deal with professional burnout, help staff respond to changes in organizational mission and structure, respond to client or customer needs, help staff meet governmental or other external demands, and provide staff with resources beyond their salaries, determine role of the program and appropriate components, ensure that the program is seen as "neutral," determine who is to be served, and develop a representative advisory counsel. (p. 3)

Further study into job satisfaction of campus recreation administrators may help determine the importance of training, preparation, and awareness of various practices that contribute to student success. Since this study did not involve an attempt at implementing or studying the effect of a professional development plan, further research that investigates whether such a plan would have an effect on overall job satisfaction of campus recreation administrators is essential. This study may serve as a starting point for more research on professional development which may lead to significantly increased satisfaction on the job and ability to test whether campus recreation administrator job satisfaction is connected to student success.

\section{Recommendations for Future Research}

This study has generated several concepts that are reported as recommendations for practice and for further study. Future research in the field of campus recreation should continue to be made to address factors that could determine the profession's long-term success on student learning and development. Although the present study used the Job Satisfaction Survey's nine variables to determine job satisfaction, various campus recreation administrators and institutions might have different variables to measure job satisfaction more effectively. Other factors or subscales may have a more direct impact on job satisfaction than those used for this study.

Because the study used a perceptual and attitudinal scale to measure job satisfaction, campus recreation administrators' answers may change with time as well as 
organizational structure, individual responsibilities, and positions. Therefore, levels of job satisfaction may change. One avenue for future research might involve conducting a follow-up with campus recreation professionals that participated in the current study to investigate whether any change occurred.

\section{Conclusion}

Results from this study indicate that there are various work environment factors within the campus recreation profession that provide campus recreation administrators at 4-year institutions a certain degree of job satisfaction. Given the practical significance of this study, institutions must take the basic steps to identify new ways to advance the campus recreation profession. There is much more to be clarified and studied within the campus recreation profession and its role in student learning and development. The literature suggested that understanding a campus recreation administrator's work environment enables a thorough connection with his or her satisfaction on the job. With continued research, new concepts and theories may be implemented to help the campus recreation profession develop its long-term outcomes towards student success.

The profession of campus recreation administration continues to progress with the implementation of new initiatives, programs, and services (Bleiklie \& Powell, 2005; S. C. Brown, 1998; Bryant et al., 1995; Cooper \& Faircloth, 2006; Lewis, Jones, Lamke, \& Dunn, 1998). Campus recreation administrators need to continue to work effectively and efficiently and dedicate their time and effort to offer a successful product. Campus recreation administrators need to be prepared to meet the demands of their job on an ongoing basis. They must be able to handle the responsibilities, duties, and expectations put upon them by their university or college and students. If they cannot handle these 
challenges, then campus recreation administrators could be faced with a varying degree of dissatisfaction with their job. 


\section{REFERENCES}

Allen, M. W., Gotcher, J. M., \& Seibert, J. H. (1993). A decade of organizational communication research: Journal articles 1980-1991. Communication Yearbook, $16,252-330$.

American College Personnel Association \& National Association of Student Personnel Administrators. (1997). Principles of good practice for student affairs. Washington, DC: Author.

American College Personnel Association. (1996). The student learning imperative: Implications for student affairs. Retrieved March 5, 2008, from http://www.acpa.nche.edu/sli/sli.htm

Amey, M. J. (2006). Leadership in higher education. Change, 38(6), 55-58.

Anderson, C. M., \& Martin, M. M. (1995). Why employees speak to coworkers and bosses: Motives, gender, and organizational satisfaction. Journal of Business Communication, 32(3), 249.

Anderson, J. L. (2005). Community service as learning. New Directions for Higher Education, 131, 37-48.

Andorka, F. H. (2003). Should you have a standard operating procedures manual? Golfdom, 59(9), 42.

Aplander, G. G., \& Lee, C. R. (1995). Culture, strategy, and teamwork. Journal of Management Development, 8/9, 15-18.

Ary, D., Jacobs, L., \& Razavieh, A. (2002). Introduction to research in education. Belmont, CA: Wadsworth/Thomson Learning.

Astin, A. W. (1993). What matters in college. San Francisco: Jossey-Bass.

Astin, A. W. (1997). What matters in college: Four critical years revisited. San Francisco: Jossey-Bass.

August, L., \& Waltman, J. (2004). Culture, climate, and contribution: Career satisfaction among female faculty. Research in Higher Education, 45(2), 177-192. 
Ayers, D. F. (2005). Organizational climate in a semiotic aspect: A postmodern community college undergoes renewal. Community College Review, 33(1), 1-21.

Babbie, E. (2007). The practice of social research (1 $11^{\text {th }}$ ed.). Belmont, CA: Wadsworth.

Bair, C. R., Keppler, W. M., \& Phelps Tobin, C. E. (1998). Institutional issues facing student affairs. In N. J. Evans \& C. E. Phelps (Eds.), The state of the art of preparation and practice in student affairs (pp. 21-46). Washington, DC: American College Personnel Association.

Baird, J. E., \& Bradley, P. H. (1978). Communication correlates of employee morale. Journal of Business Communication, 15(3), 47-56.

Baker, W. (1992). An introduction to network analysis for managers. Connections, 12, $29-48$.

Balzar, W. K., Kihm, J. A., Smith, P. C., Invin, J. L., Bachiochi, P. D., Robie, C., et al. (1997). Users manual for the Job Descriptive Index (JDI; 1997 revision) and the Job in General (JIG) scales. Bowling Green, OH: Bowling Green State University Press.

Banta, T. W., Bradley, J., \& Bryant, J. (Eds.). (1991). Quality and importance of recreational services: Technical manual and survey. Corvallis, OR: NIRSA.

Barcelona, B. (2004). Looking beyond the jockocracy: Finding competent recreational sport managers. Parks and Recreation, 39(1), 25-29.

Barcelona, B., \& Ross, C. M. (2004). An analysis of the perceived competencies of recreational sport administrators. Journal of Park and Recreation Administration, 22(4), 25-42.

Barham, J. D., \& Scott, J. H. (2006). Increasing accountability in student affairs through a new comprehensive assessment model. College Student Affairs Journal, 25(2), 209-219.

Basom, M. R., \& Frase, L. (2004). Creating optimal work environments: Exploring teacher flow experiences. Mentoring \& Tutoring: Partnerships in Learning, 12(2), 241-258.

Bauer, K. W. (2000). The front line: Satisfaction of classified employees. New Directions for Institutional Research, 2000(105), 87-97.

Bedeian, A. G, Ferris, G. R., \& Kacmar, K. M. (1992). Age, tenure and job satisfaction: A tale of two perspectives. Journal of Educational Behavior, 40(1), 33-48. 
Beehr, T. A., Glaser, K. M, Beehr, M. J., Beehr, D. E., Wallwey, D. A, Erofeev, D., et al. (2006). The nature of satisfaction with subordinates: Its predictors and importance to supervisors. Journal of Applied Social Psychology, 36(3), 1523-1547.

Belch, H. A., Gebel, M., \& Maas, G. M. (2001). Relationship between student retention and complex use, academic performance, and persistence of first-time freshman. NASPA Journal, 38, 254-268.

Birnbaum, R. (1988). How colleges work: The cybernetics of academic organization and leadership. San Francisco: Jossey-Bass.

Blake, H. (2007). The crucial role of student affairs professional in the learning process. New Directions for Student Services, 117, 65-72.

Blau, G. (1999). Testing the longitudinal impact of work variables and performance appraisal satisfaction on subsequent overall job satisfaction. Human Relations, 52(8), 1099-1113.

Bleiklie, I., \& Powell, W. W. (2005). Universities and the production of knowledge: Introduction. Higher Education, 49, 1-8.

Blimling, G. S. (2001). Uniting scholarship and communities of practice in student affairs. Journal of College Student Development, 42(4), 381-396.

Blimling, G. S., \& Whitt, E. J. (1999). Good practice in student affairs: Principles to foster student learning. San Francisco: Jossey-Bass.

Bok, D. (2003). Academic values and the lure of profit. Chronicle of Higher Education, 49(30), 7-9.

Bresciani, M. J., Zelna, C. L., \& Anderson, J. A. (2004). Assessing student learning and development. Washington, DC: NASP.

Brief, A. P., \& Weiss, H. M. (2002). Organizational behavior: Affect in the workplace. Annual Review Psychology, 53, 279-307.

Broughton, J. C., \& Griffin, D. (1994). Collegiate intramurals: Where do they go from here? National Intramural Recreation Sports Association Journal, 18(2), 10-12.

Brown, K. A., \& Mitchell, T. R. (1993). Organizational obstacles: Links with financial performance, customer satisfaction, and job satisfaction in a service environment. Human Relations, 46, 725-758.

Brown, S. C. (1998). Campus recreation. In J. B. Parks, B. R. K. Zanger, \& J. Quarterman (Eds.), Contemporary sports management (pp. 139-154). Champaign, IL: Human Kinetics. 
Bryant, J. A., Banta, T. W., \& Bradley, J. L. (1995). Assessment provides insight into the impact and effectiveness of campus recreation. NASPA Journal, 32, 153-160.

Bullock, M. B. (2005). Public good of private colleges. University Business, 8(5), 96.

Byl, J. (2002). Why intramurals? In J. Byl (Eds.), Intramural recreation: A step-by-step guide to creating an effective program (pp. 3-12). Champaign, IL: Human Kinetics.

Calhoun, C. (1998). The public good as a social and cultural project. In W. Powell \& E. Clemens (Eds.), Private action and the public good (pp. 20-35). New Haven: Yale University Press.

Carbone, J. C., \& Winston, G. C. (2004). Saving, wealth, performance, and revenues in U.S. colleges and universities. The Review of Higher Education, 28(1), 97-128.

Carini, R. M., Klein, S. P., \& Kuh, G. D. (2006). Student engagement and student learning: Testing the linkages. Research in Higher Education, 47(1), 1-32.

Carlson, J. H., \& Mellor, S. (2004). Gender-related effects in the job-design-jobsatisfaction relationship: An interactional approach. Sex Roles, 51(3/4), 237-247.

Carlton, P., \& Stinson, R. (1986). Achieving educational goals through intramurals. In Intramurals and club sports: A handbook (pp. 4-6). Reston, VA: American Alliance for Health, Physical Education, Recreation and Dance.

Cassel, R. N., \& Kolstad, R. (1998). Critical job skill requirements for $21^{\text {st }}$ century: Living and working with people. Journal of Instructional Psychology, 25(3), 176180 .

Chappell, S. K. (1995). The relationship between organizational climate and job satisfaction as reported by chief instructional officers (Doctoral dissertation, University of Florida). Dissertation Abstracts International, 56, A4290.

Chickering, A. W., \& Gamson, Z. F. (1987) Seven principles for good practice in undergraduate education. The American Association of Higher Education Bulletin, 39(7), 3-7.

Chickering, A. W., \& Gamson, Z. F. (1991). Applying the seven principles for good practice in undergraduate education. San Francisco: Jossey-Bass.

Chickering, A. W., \& Gamson, Z. F. (1999). Development and adaptations of the seven principles for good practice in undergraduate education. New Directions for Teaching and Learning, 80, 75-81. 
Clements-Croome, D. (Ed.). (2000). Creating the productive workforce. London: E \& FN Spoon.

Cohen, J. (1992). A power primer. Psychological Bulletin, 112(1), 155-159.

Cooper, N., \& Faircloth, C. (2006). Repositioning campus recreation: A case report on designing program evaluation procedures. Recreational Sports Journal, 30, 126135.

Couturier, L. K. (2005). The unspoken is being undone: The market's impact on higher education's public purpose. New Directions for Higher Education, 129, 85-100.

Crow, M. (2007). Enterprise: The path to transformation for emerging public universities. Presidency, 10(2), 24-30.

Culp, M. M. (2005). Increasing the value of traditional support services. New Directions for Community Colleges, 131, 33-49.

D'Aprix, R. (1982). The oldest (and best) way to communicate with employees. Harvard Business Review, 60(5), 30.

D'Aprix, R. M. (1996). Communicating for change: Connecting the workplace with the marketplace. San Francisco: Jossey-Bass.

Dalgarn, M. K. (2001). The role of the campus recreation center in creating a community. NIRSA Journal, 25, 66-72.

Davis, J. P. (2005). The effects of internal marketing on service quality within collegiate recreational sport: A quantitative approach. (Ph.D. dissertation, The Ohio State University, United States-Ohio). Retrieved October 8, 2007, from ProQuest Digital Dissertations database. (Publication No. AAT 3176903)

DeVaney, S. A., \& Chen, S. (2003). Job satisfaction of recent graduates in financial services. U.S. Department of Labor: Bureau of Labor Statistics. Compensation \& Working Conditions Online, Retrieved March 28, 2008, from http://www.bls.gov/opub/cwc/cm20030522ar01p1.htm

Dill, D. D. (1984). The nature of administration behavior in higher education. In M. C. Brown (Eds.), Organization and governance in higher education $\left(5^{\text {th }}\right.$ ed., pp. 92110). Boston: Pearson, ASHE Reader Series.

Downs, C., Clampitt, P., \& Pfeiffer, A. (1988). Communication and organizational outcomes. In G. Goldhaber \& G. Barnett (Eds.), Handbook of organizational communication (pp. 171-211). Norwood, NJ: Ablex. 
Ducharme, L. J., \& Martin, J. K. (2000). Unrewarding work, coworker support, and job satisfaction: A test of the buffering hypothesis. Work and Occupations, 27(2), 223-243.

Duderstadt, J. J. (2000). A university for the twenty-first century. Ann Arbor: University of Michigan Press.

Duryea, E. D. (2000). Evolution of university organization. In M. C. Brown (Eds.), Organization and governance in higher education ( $5^{\text {th }}$ ed., pp. 3-15). Boston: Pearson, ASHE Reader Series.

Eckel, P., \& Kezar, A. (2003). Key strategies for making new institutional sense. Higher Education Policy, 16(1), 39-53.

Edginton, C. R., DeGraaf, D. G., Dieser, R. B., \& Edginton, S. R. (2002). Leisure and life satisfaction: Foundational perspectivies ( $3^{\text {rd }}$ ed.). New York: McGraw-Hill Higher Education.

Ehrenberg, R. G. (2007). How governments can improve access to college. Chronicle of Higher Education, 53(31), 47.

Eisenberg, E. M., \& Goodall, H. L., Jr. (2004). Organizational communication: Balancing creativity and constraint ( $4^{\text {th }}$ ed.). Boston: Beford/St. Martin's Press.

Eisenberger, R., Fasolo, P., \& Davis-LaMastro, V . (1990). Perceived organizational support and employee diligence, commitment, and innovation. Journal of Applied Psychology, 75, 51-59.

Ellis, G. D., Compton, D. M., Tyson, B., \& Bohlig, M. (2002). Campus recreation participation, health, and quality of life. Recreational Sports Journal, 26, 51-60.

Evans, N. J., \& Phelps Tobin, C. E. (Eds.). (1998). The state of the art of preparation and practice in student affairs. Washington, DC: American College Personnel Association.

Evans, N. J., \& Williams, T. E. (1998). Student affairs faculty: Characteristics, qualifications, and recommendations for future preparation. In N. J. Evans \& C. E. Phelps (Eds.), The state of the art of preparation and practice in student affair (pp. 105-123). Washington, DC: American College Personnel Association.

Evans, N. J., Forney, D. S., \& Guido-DiBrito, F. (1998). Student development in college: Theory, research, and practice. San Francisco: Jossey-Bass.

Ewell, P. T., \& Jones, D. P. (1996). Indicators of "good practice” in undergraduate education: A handbookfor development and implementation. Boulder, CO: National Center for Higher Education Management Systems. 
Foote, E. (1999). Staff and faculty development in community colleges. Community College Journal of Research \& Practice, 23(4), 443-448.

Forrester, S. (2006). An examination of the factors contributing to student satisfaction with their overall academic experience. Schole: A journal of leisure studies and recreation education, 21, 21-33.

Fraenkel, J., \& Wallen, N. (2003). How to design and evaluate research in education. New York: McGraw-Hill.

Gall, M., Gall, J., \& Borg, W. (2003). Educational research: An introduction (7 ${ }^{\text {th }}$ ed.). Boston: Pearson Education.

Gappa, J. M., Austin, A. E., \& Trice, A. G. (2005). Rethinking academic work and workplaces. Change, 37(6), 32-39.

Garland, P. H., \& Grace, T. W. (1993). New perspectives for student affairs professionals: Evolving realities, responsibilities, and roles. San Francisco: Jossey-Bass.

Gaskins, D. A. (1992). Broadening your horizons through challenge, change, and growth. National Intramural Recreation Sports Association Journal, 41-43.

George, E. (2006). Positioning higher education for the knowledge based economy. Higher Education, 52(4), 589-610.

Gordon, W. I., Anderson, C. M., \& Bruning, S. D. (1992). Employee perceptions of corporate partnership: An affective-moral quid pro quo. Employee Responsibilities and Rights Journal, 5, 75-85.

Grace, G. G. (2002). Student affairs collaborations and partnerships. New Directions for Student Services, 100, 3-12.

Green, S. B., \& Salkind, N. J. (2005). Using SPSS for Windows: Analyzing and understanding data ( $4^{\text {th }}$ ed.). Upper Saddle River: Prentice-Hall.

Green, S. B., \& Salkind, N. J. (2008). Using SPSS for Windows and Macintosh: Analyzing and understanding data. Upper Saddle River, NJ: Pearson/Prentice Hall.

Haines, D. J. (2001). Undergraduate student benefits from university recreation. NIRSA Journal, 25, 25-33.

Hall, D. A. (2006). Participation in a campus recreation program and its effect on student retention. Recreational Sports Journal, 30(1), 40-45. 
Hamrick, F. A., Evans, N. J., \& Schuh, J. H. (2002). Foundations of student affairs practice: How philosophy, theory, and research strengthen educational outcomes. San Francisco: Jossey-Bass.

Hart, D. E., \& Carraher, S. M. (1995). The development of an instrument to measure attitudes toward benefits. Educational \& Psychological Measurement, 55(3), 480484.

Hayek, J., \& Kuh, G. (2004). Principles for assessing student engagement in the first year of college. Assessment Update, 16(2), 11-13.

Helfgot, S. R. (2005). Core values and major issues in student affairs practice: What really matters? New Directions for Community Colleges, 131, 5-18.

Henne, D., \& Locke, E. A. (1985). Job dissatisfaction: What are the consequences? International Journal of Psychology, 20, 221-240.

Heyle, L. E. (2007). An examination of the effect of job autonomy on job satisfaction. Proquest Dissertations and Theses. (UMI No. AAT 1441783)

Hirt, J. B. (2007). The student affairs profession in the academic marketplace. NASPA Journal, 44(2), 245-264.

Hirt, J. B., \& Creamer, D. (1998). Issues facing student affairs professionals: The four realms of professional life. In N. J. Evans \& C. E. Phelps (Eds.), The state of the art of preparation and practice in student affairs (pp. 47-60). Washington, DC: American College Personnel Association.

Hodson, R. (1997). Group relations at work. Work \& Occupations, 24(4), 426-452.

Holloway, E. L. (1995). Clinical supervision: A systems approach. London: Sage.

Hunt, S. K. (2003). Encouraging student involvement: An approach to teaching communication. Communication Studies, 54(2), 133-136.

Hunter, M. S., \& Murray, K. A. (2007). New frontiers for student affairs professionals: Teaching and the first-year experience. New Directions for Student Services, 117, $25-34$.

Infante, D. A., \& Gorden, W. I. (1991). How employees see the boss: Test of an argumentative and affirming model of supervisors' communicative behavior. Western Journal of Speech Communication, 56, 294-304.

Infante, D. A., Anderson, C. M., Martin, M. M., Herington, A. D., \& Kim, J. K. (1993). Subordinates' satisfaction and perceptions of superiors' compliance-gaining 
tactics, argumentativeness, verbal aggressiveness, and style. Management Communication Quarterly, 6, 307-326.

Jablin, F. M., \& Krone, K. J. (1994). Task/work relationships: A life space perspective. In M. L. Knapp \& G. R. Miller (Eds.), Handbook of interpersonal communication (pp. 621-675). Thousand Oaks, CA: Sage.

Johnson, R. A., \& Wichern, D. W. (2001). Applied multivariate statistical anaylsis $\left(5^{\text {th }}\right.$ ed.). Upper Saddle River, NJ: Pearson/Prentice Hall.

Joint Task Force on Student Learning. (1998). Powerful partnerships: A shared responsibility for learning. American Association for Higher Education, American College Personnel Association, and National Association of Student Personnel Administrators. Retrieved March 5, 2006, from http://www.myacpa.org/pub/documents/taskforce.pdf

Kalleberg, A. L., \& Mastekaasa, A. (2001). Satisfied movers, committed stayers. Work \& Occupations, 28(2), 183-205.

Katz, R. (1980). Time and work: Toward and integrative perspective. Research in Organizational Behavior, 2, 37-71.

Kezar, A, (1999). The diverse campus: Broadening our ideal to incorporate all voices. New Directions for Higher Education, 105, 25-34.

Kezar, A., \& Eckel, P. D. (2002). The effect of institutional culture on change strategies in higher education. Journal of Higher Education, 73(4), 435-460.

King, W., Lahiff, J., \& Hatfield, J. (1988). A discrepancy theory of the relationship between communication and job satisfaction. Communication Research Reports, $5,36-43$.

Kirkland, R. J. (1989). Study of job satisfaction among college union/student activities administrators (Doctoral dissertation. The Ohio State University). Dissertation Abstracts International, 50, A3656.

Klein, J. D., \& Higgins, N. (1992). Incentive contingencies, motivation, and performance in a visual learning task. Journal of Instructional Psychology, 19(2), 113-117.

Kouzes, J. M., \& Posner, B. Z. (1995). The leadership challenge. San Francisco: JosseyBass.

Kovac, D. C., \& Beck, J. E. (1997). A comparison of student perceptions, satisfaction, and patterns of participation in recreational sports. NIRSA Journal, 22, 10-12. 
Kramer, M. W., \& Noland, T. L. (1999). Communications during job promotions: A case of ongoing assimilation. Journal of Applied Communication Research, 27, 335355.

Kreiner, G. E., \& Ashforth, B. E. (2004). Evidence toward an expanded model of organizational identification. Journal of Organizational Behavior, 25, 1-27.

Kreitner, R., \& Kinicki, A. (2006). Organizational behavior. New York: McGraw Hill.

Kuh, G. (2001). The National Survey of Student Engagement: Conceptual framework and overview of psychometric properties, 1-26. Retrieved April 26, 2008, from the http://www.indiana.edu/ nsse/acrobat/framework-2001.pdf

Kuh, G. D. (2003). What we are learning about the student engagement from NSSE. Benchmarks for effective educational practices. Change, 35(2), 24-32.

Kuh, G. D., \& Associates. (2005). Student success in college: Creating conditions that matter. San Francisco: Jossey-Bass.

Kuh, G. D., Buckley, J. A., \& Kinzie, J. (2007). Piecing together the student success puzzle: Research, propositions, and recommendations. ASHE Higher Education Report, 32(5), 1-182.

Kuk, L., Cobb, B., \& Forrest, C. (2007). Perceptions of competencies of entry-level practitioners in student affairs. NASPA Journal, 44(4), 664-691.

Kulhavy, R. W., \& Schwartz, N. H. (1981). Tone of communication and climate perceptions. Journal of Business Communication, 18(1), 17-24.

Levy, S. G. (1989). Organizational climate and job satisfaction as reported by Pennsylvania community college middle-level administrators (Doctoral dissertation, Leigh University). Dissertation Abstracts International, 50, A1508.

Lewis, J. B., Barcelona, R., \& Jones, T. (2001). Leisure satisfaction and quality of life: Issues for justification of campus recreation. NIRSA Journal, 25, 57-63.

Lewis, J. B., Jones, T. R., Lamke, G., \& Dunn, M. J. (1998). Recreational sports: Making the grade on college campuses. Parks and Recreation, 33(12), 72-77.

Lindsey, R., \& Sessoms, E. (2006). Assessment of a campus recreation program on student recruitment, retention, and frequency of participation across certain demographic variables. Recreational Sports Journal, 30, 30-39.

Lipka, S. (2005). Public colleges warned on privatization. Chronicle of Higher Education, 51(36), 1. 
Llorente, R. M. B., \& Macias, E. F. (2005). Job satisfaction as an indicator of the quality of work. The Journal of Socio-Economics, 34, 656-673.

Locke, E. A. (1976). The nature and causes of job satisfaction. In M. D. Dunnette (Ed.), Handbook of industrial and organizational psychology (pp. 1297-1349). Chicago: Read McNally.

Locke, E. A., \& Latham, G. P. (1990). Work motivation and satisfaction: Light at the end of the tunnel. American Psychological Science, 1(4), 240-246.

Massey, W. E. (2001). Uncertainties in the changing academic profession. American Academic Profession, 1(1), 67-94.

Mertler, A. C., \& Vannata, A. R. (2005). Advanced and multivariate statistical methods: Practical application and interpretation $\left(3^{\text {rd }} \mathrm{ed}\right)$. Glendale, CA: Pyrczak.

Miller, T. E., Bender, B. E., Schuh, J. H., \& Associates (2005). Promoting reasonable expectations: Aligning student and institutional views of the college experience. San Francisco: Jossey-Bass.

Milton, P. (1989). Job salaries, perquisites and benefits: Can they be negotiated? Selected Readings in Recreational Sports. A collection of papers presented at the $39^{\text {th }}$ Annual NIRSA Conference, pp. 39-53.

Moore, E. L., \& Marsh, R. (2007). College teaching for student affairs professionals. New Directions for Student Services, 117, 3-11.

Morrison, T. (2002). How can values be taught in the university? Peer Review, 4(4), 4-7.

Mueller, C. W., \& Wallace, J. E. (1996). Justice and the paradox of the contented female worker. Social Psychology Quarterly, 59(4), 338-349.

Mueller, P., \& Reznik, J. W. (1979). Intramural recreational sports: Programming and administration $\left(5^{\text {th }}\right.$ ed.). New York: John Wiley \& Sons.

Mull, R. F., Bayless, K. G., Ross, C. M., \& Jamieson, L. M. (1997). Recreational sports management. Champaign, IL: Human Kinetics.

National Intramural Recreational Sports Association [NIRSA]. (2004). Value of recreational sports in higher education: Impact on student enrollment, success, and buying power. Champaign, IL: Human Kinetics.

National Intramural Recreational Sports Association [NIRSA]. (2007). Recreational Sports Directory. Corvallis, OR: Human Kinetics. 
National Intramural Recreational Sports Association [NIRSA]. (n.d.). About NIRSA. Retrieved February 9, 2007, from http://www.nirsa.org/about

National Survey of Student Engagement. (2000). The NSSE 2000 report: National benchmarks of effective educational practice. Bloomington, IN: Indiana University Center for Postsecondary Research and Planning.

Nunnally, J. C. (1967). Psychometric theory. New York: McGraw Hill.

Oburn, M. (2005). Building a culture of evidence in student affairs. New Directions for Community Colleges, 131, 19-32.

Osman, R. W., Cole, S. T., \& Vessell, C. R. (2006). Examining the role of perceived service quality in predicting user satisfaction and behavioral intentions in a campus recreation setting. Recreational Sports Journal, 30(1), 20-29.

Parkhouse, B., \& Holmen, M. (1980). Differences in job satisfaction among urban and inner-city high school physical education faculty. Research Quarterly for Exercise and Sport, 51, 654-662.

Parks, J. B., \& Parra, L. F. (1994). Job satisfaction of sport management alumni. Journal of Sport Management, 8, 49-56.

Parks, J. B., Russell, R. L., Wood, P. H., Roberton, M. A., \& Shewokis, P. A. (1995). The paradox of the contented working woman in intercollegiate athletics administration. Research Quarterly for Exercise and Sport, 66, 73-79.

Pascarella, E. T., \& Terenzini, P. T. (1991). How college affects students: Findings and insights from twenty years of research. San Francisco: Jossey-Bass.

Pascarella, E. T., \& Terenzini, P. T. (2005). How college affects students: A third decade of research (Vol. 2). San Francisco: Jossey-Bass.

Pettit, J. D., Goris, J. R., \& Vaught, B. C. (1997). An examination of organizational communication as a moderator of the relationship between job performance and job satisfaction. The Journal of Business Communication, 34(1), 81-89.

Pincus, D. (1986). Communication satisfaction, job satisfaction, and job performance. Human Communication Research, 12, 395-419.

Pratt, M. G., \& Foreman, P. O. (2000). Classifying managerial responses to multiple organizational identities. Academy of Management Review, 25, 18-42.

Reynolds, G. (2007). The impact of facilities on recruitment and retention of students. New Directions for Institutional Research, 2007(135), 63-80. 
Robertson, E. (2003). How to use a communication climate model. Strategic Communication Management, 7(2), 28-32.

Rosenfeld, L. B., Richman, J. M., \& May, S. K. (2004). Information adequacy, job satisfaction, and organizational culture in a dispersed-network organization. Journal of Applied Communication Research, 32(1), 28-54.

Ross, C. M., \& Blackman, R. J. (1998). Interview preferences: An empirical study of collegiate recreational sport administrators. NIRSA Journal, 22, 32-37.

Rubin, A. M. (1993). The effects of locus of control on communication motives, anxiety, and satisfaction. Communication Quarterly, 41, 162-171.

Rubin, R. B, \& Rubin, A. M. (1992). Antecedents of interpersonal communication motivation. Communication Quarterly, 40, 305-317.

Schneider, R. C., Stier, W. F., Kampf, S., Wilding, G., \& Haines, S. (2007). Perceived problems in campus recreation programs in North America. Recreational Sports Journal, 31, 51-60.

Schuh, J. H. (2003). Selected accountability and assessment issues. New Directions for Student Services, 103, 87-94.

Scott, M., Bailey, T., \& Kienzl, G. (2006). Relative success? Determinants of college graduation rates in public and private colleges in the U.S. Research in Higher Education, 47(3), 249-279.

Serini, S. A., Toth, E., \& Wright, D. K. (1997). Watch for falling glass . . . women, men, and job satisfaction in public relations: A preliminary analysis. Journal of Public Relations Research, 9(2), 99-118.

Serpe, R. T. (1987). Stability and change in self: A structural symbolic interactionalist explanation. Social Psychology Quarterly, 50, 44-55.

Shulman, L. S. (2002). Making differences: A table of learning. Change, 34(6), 36-45.

Sias, P. M. (2005). Workplace relationship quality and employee information experiences. Communication Studies, 56(4), 375-395.

Slack, T. (1997). Understanding sport organizations: The application of organizational theory. Champaign, IL: Human Kinetics.

Sopow, E. (2006). The impact of culture and climate on change programs. Strategic Communication Management, 10(6), 14-17. 
Spector, P. E. (1985). Measurement of human service staff satisfaction: Development of the job satisfaction survey. American Journal of Community Psychology, 13(6), 693-713.

Spector, P. E. (1997). Job satisfaction: Application, assessment, causes, and consequences. London: Sage.

Staudt, M. (1997). Correlates of job satisfaction in school social work. Social Work in Education, 19(1), 43-52.

Strauss, L. C., \& Volkwein, J. F. (2002). Comparing student performance and growth in two-year and four-year institutions. Research in Higher Education, 43(2), 133161.

Strauss, L. C., \& Volkwein, J. F. (2004). Predictors of student commitment at two-year and four-year institutions. Journal of Higher Education, 75(2), 203-227.

Taylor, H., Canning, W. F., Brailsford, P., \& Rokosz, F. (2003). Financial issues in campus recreation. New Directions for Student Services, 103, 73-86.

Terpstra, D. E., \& Honoree, A. L. (2004). Job satisfaction and pay satisfaction levels of university faculty by discipline type and by geographic region. Education, 124(3), 528-539.

Tinto, V. (1997). Universities as learning organizations. About Campus, 1(6), 2-4.

Tinto, V. (2000). What have we learned about the impact of learning communities on students? Assessment Update, 12(2), 10-12.

Tremblay, M., Sire, B., \& Balkin, D. B. (2000). The role of organizational justice in pay and employee benefit satisfaction, and its effects on work attitudes. Group \& Organization Management, 25(3), 269-290.

Tyler, P., \& Cushway, D. (1998). Stress and well-being in health-care staff: The role of negative affectivity, and perceptions of job demand and discretion. Stress Medicine, 14, 99-107.

U.S. Department of Education, Study Group on the Conditions of Excellence in American Higher Education. Involvement in learning: Realizing the potential of American higher education. Washington, DC: National Institute of Education.

Vander Putten, J., McLendon, M., \& Peterson, M. (1997). Comparing union and nonunion staff perceptions of the higher education work environment. Research in Higher Education, 38(1), 131-149. 
Varhol, P. (2000). Deciding whether or not to take the promotion. Electronic Design, 48(10), 161-162.

Viken, R. J., \& McFall, R. M. (1994). Paradox lost: Implications of contemporary reinforcement theory for behavior therapy. Current Directions in Psychological Science, 3(4), 121-125.

Vischer, J. (2007). The effects of the physical environment on job performance: Towards a theoretical model of workplace stress. Stress \& Health: Journal of the International Society of the Investigation of Stress, 23(3), 175-184.

Volkwein, J. F., \& Malik, S. M. (1997). State regulation and administrative flexibility at public universities. Research in Higher Education, 38(1), 17-42.

Wald, W. J. (2000, January/February). Is your agency a learning organization? Illinois Parks and Recreation, pp. 8-9.

Walter, S., \& Eodice, M. (2005). Meeting the student learning imperative: Supporting and sustaining collaboration between academic libraries and student services programs. Research Strategies, 20(4), 219-225.

Weathington, B. L., \& Tetrick, L. E. (2000). Compensation or right: An analysis of employee "fringe" benefit perception. Employee Responsibilities and Rights Journal, 12(3), 141-162.

Weese, W. J. (1997). The development of an instrument to measure effectiveness in campus recreation programs. Journal of Sport Management, 11, 263-274.

Wheatley, M. J. (2001). Leadership and the new science: Discovering order in a chaotic world. San Francisco: Berrett-Koehler.

Wilkinson, R., \& Yussof, I. (2005). Public and private provisions of higher education in Malaysia: A comparative analysis. Higher Education, 50, 361-386.

Woodard, D. (1998). Societal influences on higher education and student affairs. In N. J. Evans \& C. E. Phelps (Eds.), The state of the art of preparation and practice in student affairs (pp. 3-20). Washington, DC: American College Personnel Association.

Young, S. J., \& Ross, C. M. (1998). Recreational sports trends for the $21^{\text {st }}$ century: Results of a delphi study. National Intramural Recreation Sports Association, 24(2), 24-37.

Zhang, J. J., DeMichele, D. J., \& Connaughton, D. P. (2004). Job satisfaction among mid-level collegiate campus recreation program administrators. Journal of Sport Behavior, 27(2), 184-212. 
Zhao, C. M., \& Kuh, G. D. (2004). Adding value: Learning communities and student engagement. Research in Higher Education, 45(2), 115-138. 
APPENDICES 


\section{APPENDIX A \\ QUESTIONNAIRE \\ Job Satisfaction Survey (JSS) \\ Paul E. Spector}

\section{Campus Recreation Administrators}

Directions: The Job Satisfaction Survey (JSS) is designed to identify aspects of the job that influence job satisfaction among campus recreation administrators and focuses on the following three areas: professional data, personal data, and professional attitudes. Please provide the information in the format requested.

\section{PART I: PROFESSIONAL DATA}

\section{Current Position}

Years in current position:

Less then 1 year

[ ]

$2-3$ years

$4-5$ years

More then 6 years
Type of Institution:

Public [ ] Private [ ]

Student Population (head count) of campus:

$\begin{array}{rr}0-5,000 & \text { [ ] } \\ 5,001-15,000 & \text { [ ] } \\ 15,001-25,000 & \text { [ ] } \\ 25,001-40,000 & \text { [ ] } \\ 40,001+ & \text { [ ] }\end{array}$




\section{PART III: PERSONAL INFORMATION}

Age:

$\begin{array}{ll}18-25 & \text { [ ] } \\ 26-35 & \text { [ ] } \\ 36-45 & \text { [ ] } \\ 46-55 & \text { [ ] } \\ 60+ & \text { [ ] }\end{array}$

Gender:

Male [ ]

Female [ ]

Please return this instrument in the self-addressed, stamped envelope provided to:

Lance Kaltenbaugh

2237 Allium Place

West Salem, OH 44287 


\begin{tabular}{|c|c|c|}
\hline & $\begin{array}{c}\text { JOB SA TISFACTION SURVEY } \\
\text { Paul E. Spector } \\
\text { Copyright Paul E. Spector 1994, All rights reserved. }\end{array}$ & \\
\hline & $\begin{array}{l}\text { PLEASE CIRCLE THE ONE NUMBER FOR EACH QUESTION THAT } \\
\text { COMES CLOSEST TO REFLECTING YOUR OPINION ABOUT IT. }\end{array}$ & 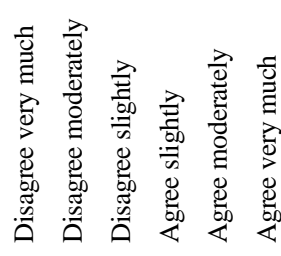 \\
\hline 1 & I feel I am being paid a fair amount for the work I do. & $\begin{array}{llllll}1 & 2 & 3 & 4 & 5 & 6\end{array}$ \\
\hline 2 & There is really too little chance for promotion on my job. & $\begin{array}{llllll}1 & 2 & 3 & 4 & 5 & 6\end{array}$ \\
\hline 3 & My supervisor is quite competent in doing his/her job. & $\begin{array}{llllll}1 & 2 & 3 & 4 & 5 & 6\end{array}$ \\
\hline 4 & I am not satisfied with the benefits I receive. & $\begin{array}{llllll}1 & 2 & 3 & 4 & 5 & 6\end{array}$ \\
\hline 5 & $\begin{array}{l}\text { When I do a good job, I receive the recognition for it that I should } \\
\text { receive. }\end{array}$ & $\begin{array}{llllll}1 & 2 & 3 & 4 & 5 & 6\end{array}$ \\
\hline 6 & Many of our rules and procedures make doing a good job difficult. & $\begin{array}{llllll}1 & 2 & 3 & 4 & 5 & 6\end{array}$ \\
\hline 7 & I like the people I work with. & $\begin{array}{llllll}1 & 2 & 3 & 4 & 5 & 6\end{array}$ \\
\hline 8 & I sometimes feel my job is meaningless. & $\begin{array}{llllll}1 & 2 & 3 & 4 & 5 & 6\end{array}$ \\
\hline 9 & Communications seem good within this organization. & $\begin{array}{llllll}1 & 2 & 3 & 4 & 5 & 6\end{array}$ \\
\hline 10 & Raises are too few and far between. & $\begin{array}{llllll}1 & 2 & 3 & 4 & 5 & 6\end{array}$ \\
\hline 11 & Those who do well on the job stand a fair chance of being promoted. & $\begin{array}{llllll}1 & 2 & 3 & 4 & 5 & 6\end{array}$ \\
\hline 12 & My supervisor is unfair to me. & $\begin{array}{llllll}1 & 2 & 3 & 4 & 5 & 6\end{array}$ \\
\hline 13 & The benefits we receive are as good as most other organizations offer. & $\begin{array}{llllll}1 & 2 & 3 & 4 & 5 & 6\end{array}$ \\
\hline 14 & I do not feel that the work I do is appreciated. & $\begin{array}{llllll}1 & 2 & 3 & 4 & 5 & 6\end{array}$ \\
\hline 15 & My efforts to do a good job are seldom blocked by red tape. & $\begin{array}{llllll}1 & 2 & 3 & 4 & 5 & 6\end{array}$ \\
\hline 16 & $\begin{array}{l}\text { I find I have to work harder at my job because of the incompetence of } \\
\text { people I work with. }\end{array}$ & $\begin{array}{llllll}1 & 2 & 3 & 4 & 5 & 6\end{array}$ \\
\hline 17 & I like doing the things I do at work. & $\begin{array}{llllll}1 & 2 & 3 & 4 & 5 & 6\end{array}$ \\
\hline 18 & The goals of this organization are not clear to me. & $\begin{array}{llllll}1 & 2 & 3 & 4 & 5 & 6\end{array}$ \\
\hline
\end{tabular}




\begin{tabular}{|c|c|c|c|c|c|c|c|}
\hline & $\begin{array}{l}\text { PLEASE CIRCLE THE ONE NUMBER FOR EACH QUESTION THAT } \\
\text { COMES CLOSEST TO REFLECTING YOUR OPINIONABOUT IT. } \\
\qquad \text { Copyright Paul E. Spector 1994, All rights reserved. }\end{array}$ & 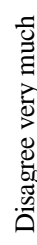 & 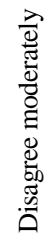 & 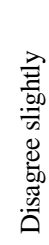 & 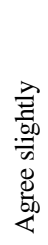 & 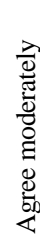 & 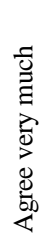 \\
\hline 19 & $\begin{array}{l}\text { I feel unappreciated by the organization when I think about what they } \\
\text { pay me. }\end{array}$ & 1 & 2 & 3 & 4 & 5 & 6 \\
\hline 20 & People get ahead as fast here as they do in other places. & & 2 & 3 & 4 & 5 & \\
\hline 21 & My supervisor shows too little interest in the feelings of subordinates. & 1 & 2 & 3 & 4 & 5 & \\
\hline 22 & The benefit package we have is equitable. & 1 & 2 & 3 & 4 & 5 & 6 \\
\hline 23 & There are few rewards for those who work here. & 1 & 2 & 3 & 4 & 5 & \\
\hline 24 & I have too much to do at work. & 1 & 2 & 3 & 4 & 5 & \\
\hline 25 & I enjoy my coworkers. & 1 & 2 & 3 & 4 & 5 & 6 \\
\hline 26 & I often feel that I do not know what is going on with the organization. & 1 & 2 & 3 & 4 & 5 & \\
\hline 27 & I feel a sense of pride in doing my job. & 1 & 2 & 3 & 4 & 5 & 6 \\
\hline 28 & I feel satisfied with my chances for salary increases. & 1 & 2 & 3 & 4 & 5 & \\
\hline 29 & There are benefits we do not have which we should have. & 1 & 2 & 3 & 4 & 5 & \\
\hline 30 & I like my supervisor. & 1 & 2 & 3 & 4 & 5 & 6 \\
\hline 31 & I have too much paperwork. & 1 & 2 & 3 & 4 & 5 & \\
\hline 32 & I don't feel my efforts are rewarded the way they should be. & & 2 & 3 & 4 & 5 & \\
\hline 33 & I am satisfied with my chances for promotion. & 1 & 2 & 3 & 4 & 5 & \\
\hline 34 & There is too much bickering and fighting at work. & 1 & 2 & 3 & 4 & 5 & \\
\hline 35 & My job is enjoyable. & 1 & 2 & 3 & 4 & 5 & 6 \\
\hline 36 & Work assignments are not fully explained. & 1 & 2 & 3 & 4 & 5 & \\
\hline
\end{tabular}




\section{APPENDIX B}

\section{DESCRIPTION OF EXPERT PANEL}

\section{Sean Ries}

Director of Recreational Sports, Ashland University 401 College Ave. Ashland, OH 44805

Janel Crabel

Assistant Director of Facilities Ashland University

401 College Ave.

Ashland, OH 44805

Jill Sturts

Assistant Director of Programs

Ashland University

401 College Ave.

Ashland, OH 44805 


\section{APPENDIX C PROFESSIONAL COMMENT FORM}

1. Does the instrument address the purpose and objectives of the study?

Yes No

2. Are there any items that are lacking in content or meaning?

Yes No

3. Are there any items lacking clarity?

Yes No

4. Is the instrument too long?

Yes No

5. Is the format attractive in appearance?

Yes No

6. Are the directions clear?

Yes No

7. Is the format of the instrument appropriate?

Yes $\quad$ No

8. Are the demographics questions appropriate and easy to complete?

Yes No

9. Are there demographic questions which should or should not be asked?

Yes No If YES, explain

10. Are there any confusing terms in any of the items?

Yes No If YES, explain

108 


\section{APPENDIX D STUDENT COMMENT FORM}

11. Are there any items that are lacking in content or meaning?

$$
\text { Yes No }
$$

12. Are there any items lacking clarity?

Yes No

13. Is the instrument too long?

Yes No

14. Is the format attractive in appearance?

Yes No

15. Are the directions clear?

Yes No

16. Is the format of the instrument appropriate?

Yes No

17. Are the demographics questions appropriate and easy to complete?

Yes No

18. Are there demographic questions which should or should not be asked?

Yes No If YES, explain

19. Are there any confusing terms in any of the items?

Yes No If YES, explain 


\section{APPENDIX E}

\section{IRB APPROVAL}

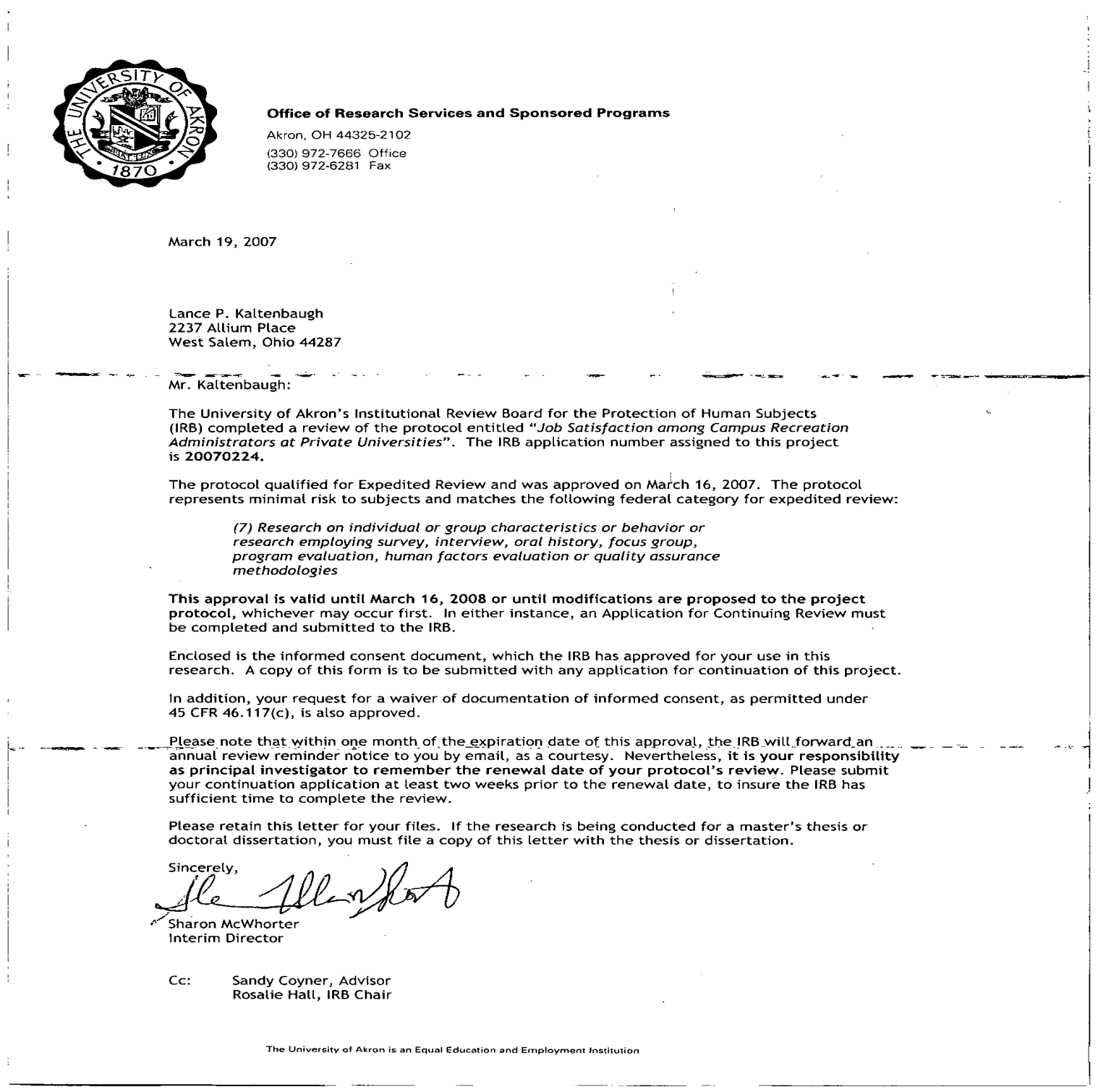




\section{APPENDIX F}

\section{COVER LETTER - FIRST MAILING}

\section{Dear <FirstName $>$ :}

It is my hope that you will take a few moments of your time to share with me your valuable expertise as university campus recreation administrator. Currently, I am a doctoral student of the Educational Foundations and Leadership program at the University of Akron in Ohio writing my dissertation on job satisfaction among campus recreation administrators. The general purpose of this research is to investigate aspects of the job that influence job satisfaction among campus recreation administrators at 4-year private institutions. The demands for productivity, knowledge of skills and abilities, and the responsibilities to plan, guide, and lead his or her organization into the future are having an effect on the overall satisfaction administrators have for the campus recreation profession.

I am asking for your cooperation in advancing this study. Enclosed is a job satisfaction questionnaire that should take approximately fifteen minutes of your time to complete. Your participation is strictly voluntary; you may choose not to participate or to discontinue at any time without penalty or prejudice. Both the questions and method of distribution of this survey have been evaluated and approved by the Department and The University of Akron's Institutional Review Board for Protection of Human Subjects. For more information about your rights as a human research participant, please contact Ms. Sharon McWhorter, Interim Director, Research Services at 330-972-7666 or 1-888-232-8790 (toll-free).

By completing this survey, you are giving consent for participation. Your participation is voluntary and there is no penalty if you do not participate. I do not know of any risks to you if you decide to participate in this survey and I guarantee that all information that you provide will be kept confidential. Participant's names and department names will never be used, and all survey results will be reported in summary form only. If you wish to participate in the study, please complete the questionnaire, and place it inside the smaller self-addressed, postage paid envelope and return it to me by <Return Date>.

Your participation is an extremely important first step to help us all better understand the profession. If campus recreation administrators are to help in developing better people for tomorrow, we must learn about how aspects of the job affect our own lives and work. Please do consider responding to the survey and I thank you in advance for you help.

If you want to know more about this research project, please call me, or my advisor at the numbers below.

Sincerely,

Lance P. Kaltenbaugh

Ashland University

401 College Ave.

Ashland, $\mathrm{OH} 44805$

(419) 289-5477
Advisor: Dr. Sandy Coyner

The University of Akron

Zook Hall 301

Akron, $\mathrm{OH}$ 44325-4208

(330) 972-5822 


\section{APPENDIX G \\ POST CARD - SECOND MAILING}

Dear (use name),

Approximately ten days ago, a questionnaire was mailed to you seeking your opinions on job satisfaction among campus recreation administrators. If you have already completed and returned the questionnaire, please accept my sincere thanks. If not, I would be extremely grateful if you could forward it today.

If you did not receive a questionnaire, or if it was misplaced, please email me at

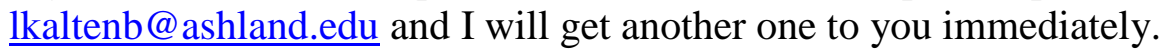

Sincerely,

Lance Kaltenbaugh

Ashland University

401 College Ave.

Ashland, $\mathrm{OH} 44805$ 


\section{APPENDIX H \\ COVER LETTER - THIRD MAILING}

$<$ Date>

$<$ FirstName $><$ LastName $>$

$<$ School>

$<$ Department $>$

$<$ Address 1>

$<$ City $\rangle,<$ State $>\langle$ PostalCode $>$

Dear <FirstName>:

Recently, I requested your help in a study of job satisfaction among campus recreation administrators. Your feedback in this research is particularly valued since you are deeply involved in the field of recreational sports. To date, participation has been outstanding as over $\langle \%\rangle$ of the individual contacted have responded. Naturally, the validity of the findings will be enhanced if more individuals participate and respond to the survey. It is my hope that you will take a few moments of your time to share with me your valuable expertise as a campus recreation administrator.

I am asking for your cooperation in advancing this study. Enclosed is a job satisfaction questionnaire that should take approximately fifteen minutes of your time to complete. As indicated in the earlier mailing, your responses will be held in strictest confidence.

If you still wish to participate in the study, please complete the questionnaire, and place it inside the smaller self-addressed, postage paid envelope and return it to me by <Return Date>.

Your participation is an extremely important first step to help us all better understand the profession. If you want to know more about this research project, please call me, or my advisor at the numbers listed below. If you would like to receive a brief summary of the results of the study when it is concluded, please indicate so on the questionnaire.

Sincerely,

Lance P. Kaltenbaugh

Ashland University

401 College Ave.

Ashland, $\mathrm{OH} 44805$

(419) 289-5477
Advisor: Dr. Sandy Coyner

The University of Akron

Zook Hall 301

Akron, $\mathrm{OH}$ 44325-4208

(330) 972-5822 
APPENDIX I

SUMMARY OF PARTICIPANT RESPONSES TO JOB SATISFACTION SURVEY

\begin{tabular}{|c|c|c|c|}
\hline & Subscale & Mean & $\begin{array}{c}\text { Std. } \\
\text { Deviation }\end{array}$ \\
\hline ITEM 1 & Pay & 4.06 & 1.582 \\
\hline ITEM 2 & Promotion & 2.85 & 1.419 \\
\hline ITEM 3 & Supervision & 4.91 & 1.224 \\
\hline ITEM 4 & Fringe Benefits & 4.36 & 1.551 \\
\hline ITEM 5 & Contingent rewards & 4.25 & 1.244 \\
\hline ITEM 6 & Operating conditions & 2.85 & 1.419 \\
\hline ITEM 7 & Coworkers & 5.52 & 0.638 \\
\hline ITEM 8 & Nature of work & 5.19 & 0.966 \\
\hline ITEM 9 & Communication & 4.03 & 1.296 \\
\hline ITEM 10 & Pay & 2.97 & 1.542 \\
\hline ITEM 11 & Promotion & 3.47 & 1.314 \\
\hline ITEM 12 & Supervision & 5.37 & 1.166 \\
\hline ITEM 13 & Fringe Benefits & 4.68 & 1.346 \\
\hline ITEM 14 & Contingent rewards & 4.39 & 1.318 \\
\hline ITEM 15 & Operating conditions & 5.37 & 1.166 \\
\hline ITEM 16 & Coworkers & 4.33 & 1.390 \\
\hline ITEM 17 & Nature of work & 5.37 & 0.801 \\
\hline
\end{tabular}




\begin{tabular}{|c|c|c|c|}
\hline & Subscale & Mean & $\begin{array}{c}\text { Std. } \\
\text { Deviation }\end{array}$ \\
\hline ITEM 18 & Communication & 4.69 & 1.239 \\
\hline ITEM 19 & Pay & 3.94 & 1.487 \\
\hline ITEM 20 & Promotion & 3.13 & 1.166 \\
\hline ITEM 21 & Supervision & 4.89 & 1.358 \\
\hline ITEM 22 & Fringe Benefits & 4.51 & 1.400 \\
\hline ITEM 23 & Contingent rewards & 3.88 & 1.225 \\
\hline ITEM 24 & Operating conditions & 5.27 & 1.134 \\
\hline ITEM 25 & Coworkers & 5.27 & 0.815 \\
\hline ITEM 26 & Communication & 4.41 & 1.243 \\
\hline ITEM 27 & Nature of work & 5.39 & 0.730 \\
\hline ITEM 28 & Pay & 3.35 & 1.447 \\
\hline ITEM 29 & Fringe Benefits & 3.67 & 1.431 \\
\hline ITEM 30 & Supervision & 5.27 & 1.134 \\
\hline ITEM 31 & Operating conditions & 4.37 & 1.401 \\
\hline ITEM 32 & Contingent rewards & 3.66 & 1.348 \\
\hline ITEM 33 & Promotion & 3.09 & 1.345 \\
\hline ITEM 34 & Coworkers & 4.69 & 1.337 \\
\hline ITEM 35 & Nature of work & 5.33 & 0.756 \\
\hline ITEM 36 & Communication & 4.37 & 1.401 \\
\hline
\end{tabular}

